\title{
What determines own-account work in Colombia? Some empirical evidence for the years 2010 and 2013
}

\author{
Burbano VALLEJo, Edy LORENA \\ Universidad de San Buenaventura (Colombia) \\ Correo electrónico: elburban@usbcali.edu.co \\ CASTRO ARISTIZABAL, GEOVANNY \\ Universidad Autónoma de Bucaramanga (Colombia) \\ Correo electrónico: gcastro793@unab.edu.co \\ Castillo Caicedo, Maribel \\ Pontificia Universidad Javeriana (Colombia) \\ Correo electrónico: mabelcas@javerianacali.edu.co
}

\begin{abstract}
The main objective of this paper is to analyze the effect of education, age, access to ICTs and physical and financial assets, as well as other personal and socioeconomic characteristics on the probability of being a formal or informal ownaccount worker. In order to achieve this purpose, information will be used at the urban level for the twenty-one main cities in Colombia from the Great Integrated Household Survey 2010 (GISH), by the National Administrative Department of Statistics (DANE) and the Colombian Longitudinal Survey of the University of the Andes 2013 (CLS). Based on these data, models that have a qualitative binomial and multinomial dependent variable are employed, correcting for selection bias. As main results, it was found that physical assets and access to credit have a positive marginal effect on the probability of being an own-account worker. On the other hand, the marginal effect of education was negative; the lower the educational level, the greater the probability of self-employment, especially regarding the informal work.
\end{abstract}

Keywords: Labor Economics, own-account worker, binomial and multinomial models, Colombia.

JEL classification: C13; C51; J01; J24.

MSC2010: 91B24; 91B39; 91B70; 91B82.

Artículo recibido el 27 de marzo de 2019 y aceptado el 17 de mayo de 2021. 


\title{
¿Qué determina el trabajo por cuenta propia en Colombia? Una evidencia empírica para los años 2010 y 2013
}

\begin{abstract}
RESUMEN
El objetivo principal del presente trabajo es analizar el efecto que tiene la educación, la edad, el acceso a TIC's y activos físicos y financieros, además de otras características personales y socioeconómicas, en la probabilidad de ser trabajador por cuenta propia, formal e informal. Para el logro de este propósito, se emplea la información a nivel urbano para las 21 ciudades principales en Colombia, de la Gran Encuesta Integrada de Hogares (GEIH), del Departamento Administrativo Nacional de Estadística (DANE), y de la Encuesta Longitudinal Colombiana de la Universidad de los Andes (ELCA), para 2010 y 2013, aplicando los modelos de variable policótoma, corrigiendo el sesgo de selección. Como principales resultados, se encontraron que los activos físicos y el acceso al crédito, tienen un efecto marginal positivo sobre la probabilidad de ser trabajador por cuenta propia. De otra parte, el efecto marginal de la educación fue negativo: a menor nivel educativo, mayor la probabilidad de autoempleo, sobre todo el informal.
\end{abstract}

Palabras clave: economía laboral, trabajador cuenta propia, modelos binomiales y multinomiales, Colombia.

Clasificación JEL: C13; C51; J01; J24.

MSC2010: 91B24; 91B39; 91B70; 91B82.

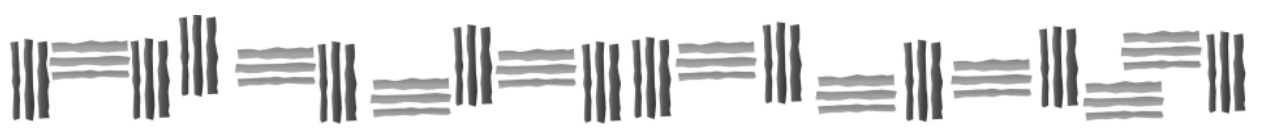




\section{Introduction.}

According to DANE, an own-account worker is an individual who earns income independently, based on formal or informal economic activities. The aforementioned workers were made up of an important fraction of the employed population in the Colombian labor market. According to DANE, they represented 43\% of the total of employed people in the country between 2011 and 2015.

Generally, informal own-account workers are individuals who creates a small business, or who works alone and independent, finding a last resource for income when facing the possibility of selfemployment. More than representing an opportunity, independent work usually represents a necessity amid an environment without barriers with few physical and human capitals, addressed to activities, which create little aggregate value (Tokman, 1987). Likewise, there are formal own-account workers, who are not linked to the company through a direct contract, their relationship with it is through a service provision contract, for example, consultant, plumber, electrician, who find an alternative source of income and maintain a good life quality, without complying with schedule or direct labor hiring (Uribe \& Ortiz, 2004; Guataquí, García, \& Rodríguez, 2011).

Own-account workers in developed countries also represent a high proportion of its labor market, reaching up to $30 \%$ of participation. However, unlike developing countries such as Colombia, these self-employed workers have better economic and political conditions, as well as physical and human capital (Blanchflower, 2004).

Nevertheless, in order to study this segment of the labor market, economics has employed selfemployment models, which have been evolving since the late seventies of last century, and have also been trying to find explanations in terms of behavior and structure of own-account workers. The most recent theoretical developments have incorporated Mortensen-Pissarides' models (1994) of balanced unemployment into the different stages of the labor market, including the self-employment condition (see Bradley (2014) and Kumar \& Schuetze (2007)). This addition obeys to evidence of significant flows from unemployment to self-employment in developed countries, based on the limited growth of employment and the improvement of salaries (Blanchflower, 2004); apart from the increasing gap between the average income level of a self-employed individual and a wage-earner, taking into account, this individual's educational level (Hamilton, 2000).

On the other hand, considering the Colombian case, studies that have contrasted the hypothesis about the structure, behavior and/or factors that affect the composition of own-account population, are relatively scarce. Meanwhile, there is abundant literature about the analysis of labor informality, including companies and employers, mainly from the nineties (Guataquí et al., 2011; Mondragón \& Peña, 2010; García, 2005; Uribe \& Ortiz, 2004; Ribero, 2003; Flórez, 2002; Núñez, 2002; Caro, 1995; among others).

Taking into account the aforementioned, this work seeks to determine which are the main factors that affect the decision of being a formal or an informal own-account worker in Colombia. Based on data from the Great Integrated Household Survey (GIHS) by DANE for 2010 and on the Colombian Longitudinal Survey (CLS) by the University of the Andes for 2013, this work includes twenty-one main cities in the urban context. Binomial and multinomial models are employed, which incorporate polychotomous variables and the correction of selection bias, by means of the proposed model by Heckman (1976; 1979).

The purpose here is to study the socio-economic structure of own-account workers for 2010 and 2013, quantify the marginal effects that the possession of assets and access to credit have on the probability of being a self-employed worker, and updating and/or contrasting results to those of other previous related research.

Two main contributions are established in this article: first, from the perspective of the category of self-employment and second, from the methodology. In relation to the first one, and based on the 
literature review, unlike others, this work carries out the study of self-employment by disaggregating between formal and informal own-account workers, considering the institutional approach. Likewise, it incorporates physical and financial assets as a possible determining factor in the decision of being self-employed, based on data from the CLS, 2010 and 2013; therefore, decreasing the relative scarcity in this type of studies for the Colombian case. Now, considering the methodological perspective, this research incorporates the methodology by Heckman $(1979 ; 1976)$ in the estimations of the binomial and multinomial models, in order to correct for selection bias created by the decision of individuals regarding their occupation; which is an aspect that had not been found in previous works to this one.

This document is organized as follows. After this introduction, backgrounds of international and national literature related to self-employment and its applications on own-account work are included. Afterwards, the methodology of the binomial and multinomial models, and the correction of selection bias are described. Results obtained in this study, including descriptive statistics of the employed variables are presented in the fourth section. Finally, conclusions and bibliographic references are included.

\section{Background framework.}

According to Evans and Leighton (1989), the first studies about small businesses and self-employment correspond to the ones carried out by Knight (1921) and Schumpeter (1950). Subsequently, research by Kihlstrom and Laffont (1979), Lucas (1978), Calvo and Wellisz (1980) and Evans and Jovanovic (1989) appeared. These studies showed that the decision to undertake a business venture was associated with: a) preferences related to risk, b) expectations and abilities of individuals to undertake a business venture, c) learning and knowledge of entrepreneur-related skills, associated to age and the learning ability of people, and d) liquidity problems and the difficult access to credit.

By the nineties, based on the proposals by Lucas (1978), Jovanovic (1989) highlighted the importance of the role of individuals with superior attributes to face the idea of undertaking a productive business. Therefore, in addition to access to capital and risk aversion, the distribution of business-related abilities plays a quite important role in society. From here, that the most audacious individuals, with better capacities and managerial predispositions, assume the challenge to undertake own-account businesses. Later on, Blanchflower and Oswald (1998) determined that access to capital was highly important to entrepreneurship, in addition to talent and vocation of entrepreneurship included in Lucas's model (1978). This finding follows the same line as the models by Evans and Jovanovic (1989).

More recently, Hurst and Pugsley (2010) proposed that the decision of being a wage-earner or a self-employed worker depended on the non-pecuniary benefits. They suggest that individuals (households) face a disjunctive: working in their own business, which generates as much benefit as utility (being their own boss), or working for a company, which produces income via salary. In this way, in spite of the fact that an own-account worker might have low income, these are compensated with the non-pecuniary benefits, given the utility or satisfaction that being his own boss represents; and in this way, he decides to undertake his own company.

These approaches have received different criticism. The most important one refers to the fact that the proposed models do not consider the irregularities of the labor market, since they assume a context of perfect competition. Therefore, they do not take into account unemployment, its duration, the costs of search for employment, the market's rigidities or the imbalances between supply and demand (dismatch). For this reason, new approaches have been developed. These are mentioned as follows.

Based on the survey of the Panel Study of Income Dynamics from 1977 to 1996 for the United States and on the model of balanced unemployment by Mortensen and Pissarides (1994), Kumar and Schuetze (2007) analyzed the effect of variations in the minimum wage and unemployment insurance on the transitions between unemployment and being an own-account worker. They found that a high 
unemployment insurance and the fixing of a minimum wage decreased both the probability of being a self-employed worker and the probability of transition from unemployment to self-employment.

On its part, Bradley (2014) developed a model of balanced unemployment with frictions, distinguishing between a full-time own-account worker and an own-account worker with the possibility of hiring people (employer). By means of the British Household Panel Survey for 2004-2008, the author demonstrated that while the former are more productive than large companies are, they have difficulties to grow, since they are restricted by their technology capacity. Likewise, based on the Labor Force Survey of Brazil for 2002-2007, Meghir et al. (2015) introduced the own-account sector and informality in a model of balanced unemployment. They showed that decisions on transitions between the different stages of the labor market depended on the future perspective of the stage in which individuals were found and not only on the offered or earned salary at that time.

These research have been oriented to the search of factors that determine the decision of selecting self-employment; however, they have made no distinction between what informal own-account work and formal own-account work mean. Taking into consideration that this work does make that distinction, literature review regarding this topic, in particular for the Colombian case, is presented as follows.

The analysis of labor informality took place in the frame of the theory of segmented labor markets, based on the dual labor market theory by Cain (1976) and Dickens and Lang (1988), which supports the coexistence of two economic sectors, with different characteristics and clearly differentiated hiring patterns. Subsequently, Maloney (2004) defined the informal sector as that in which the absence of state regulation and lack of compliance of institutional requirements existed. Such definition has been endorsed by the World Bank (WB) and the Inter-American Development Bank (IDB) for the Latin American case, for the last ten years.

In this Latin American context, there are two views regarding informality: a) the structuralist view, which is adopted by the Regional Employment Program for Latin America (REPLA), the International Labor Organization (ILO) and DANE (National Statistics Administrative Department) for Colombia; and b) the institutional view, which is accepted by the WB and IDB. In the first one, ownaccount workers, employees in companies of less than five people, domestic service workers and unpaid family workers are catalogued as informal workers (except for professional workers). The second view emphasizes more the norms and regulations of the labor market (payment of minimum wage, pensions, severances, semi-fiscals), which when considering the size of the business establishment, confers greater relevance to working conditions (Uribe \& Ortiz, 2004; Guataquí, García, \& Rodríguez, 2011).

For the case of the studies employed in Colombia, literature is relatively scarce, and it is mostly oriented towards the determining factors that affect the choice of being an own-account worker. For instance, Destré and Henrard (2004) and Guataquí et al. (2009) determined educational level of individuals as one of the main conditioning factors. Based on the National Household Survey 1996 (NHS), the latter found a negative effect of education on the probability of being an own-account worker. Now, based on the Great Integrated Household Survey 2007, the former found that returns of these workers were associated to their educational level.

In line with this, Mondragón and Peña (2010) carried out a comparision between businessmen and self-employed own-account workers in Colombia, from the data contained in the National Household Survey between 1984 and 2006. They found that there was a high proportion of own-account workers, with basic educational level; while businessmen were, in a great percentage, individuals with higher education, who also, doubled own-account workers in terms of quantity. In a study carried out for Ibagué with data from the NHS for 2003, 2005 and 2007, Salinas and Aragón (2011) found that additional years of education negatively affected income of own-account workers (exceptional case, the ones with higher education), although had a positive influence on income of wage-earners. 
Using data from the Survey of the National Government of the program "Familias en Acción" and from the National Department of Planning (NDP), Bozzoli et al. (2011) determined that ownaccount work increased accordingly with the increase in the displacement rates in the rural and urban zones, and that homicides had a negative effect on the possibility to undertake self-employment. Based on data by the Centre of Studies on Economic Development (CSED) from the University of the Andes, the Survey of the National Government of the program "Familias en Acción" provided municipal data on violence and conflict. Data regarding the economic situation of Colombian municipalities was provided by the National Department of Planning (NDP).

Finally, in the work carried out by Aparicio et al. (2013) for Medellín, there was evidence that education, financial capital and the use of ICT's, positively affected the decision of becoming a selfemployed business person, which generated employment. This conclusion is based on data from the GIHS 2009.

Sánchez (2018) makes a characterization of own-account workers in Colombia, between 2002 and 2016. The author finds that they have a low remuneration, as well as a low educational level and a large part of the population that engages in these activities is over 40 years of age. In addition, they face high risks in the execution of their activity given the poor conditions in which they exercise it, and they suffer from labor exploitation. In addition, Suárez (2020) identifies that in Colombia, for the year 2019, most of the own-account workers do not have a labor contract, they are concentrated in the commercial and agricultural sectors, and the average labor income of salaried employees doubles average earnings of self-employed workers.

As can be seen, in general, these research did not carry out a distinction between formal and informal own-account workers, neither did they include physical and financial capital as a possible determining factor in the decision of being self-employed, which it is taken into consideration in this work, under the institutional view of informal work. This would be the main contribution of this work. On the other hand, from the methodological view, the estimations of the binomial and multinomial models are carried out correcting for selection bias between the decision of being an own-account worker and the income level; which represents an aspect not taken into account in the previous research, except for Destré and Henrad (2004). These authors correct this bias for the case of Mincer equations, but not for the choice equations, which is the case presented in this study and so, this represents its second contribution.

\section{Methodology for the empirical analysis.}

The empirical analysis examined in this work closely follows two information sources: the GIHS, by DANE and the CLS, by the University of the Andes. Data for 2010 and 2013 at the urban level, were obtained for the twenty-one main cities in Colombia. The analysis was carried out for the population older than eighteen years old; basically since it is the population with access to physical and financial assets. For the descriptive analysis, the corresponding expansion factors were employed in each one of the surveys. Moreover, the differentiation between formal and informal own-account workers was carried out based on the institutional approach.

It is worth mentioning that using these two sources of information as a reference was due to the complementarity that the CLS provides to the analyses on own-account workers, explicitly related to the acquisition and easy access to assets (both physical and financial). This enables to empirically evaluate the Colombian case, in the light of the theoretical framework. 


\subsection{Analysis of variables.}

For the econometric estimations, binomial and multinomial probability models that employ qualitative variables with several categories (polychotomous) as the dependent variable, have been included in this study. In this way, to calculate the binomial probabilities on the decision of being an own-account worker, the dependent variable is a binary variable and indicates the value of 1 when the individual is an own-account worker, and 0 if he is not. In relation to the multinomial choice, five occupational categories will be analyzed: informal own-account, formal own-account, self-employed worker, government employee and other types of employment.

In regards to the explanatory variables, three categories have been grouped together: 1) those related to human capital, as educational level and age; 2) socio-economic variables such as the position in the household (head of household), marital status, ability to use information technology (ICT's) and duration of employment; 3 ) those related to physical and financial assets, such as the ownership of residential property, other buildings, an automobile, other means of transportation and the access to credit with commercial banks and financial institutions. The variables included in the model are described in Table 1.

Table 1. Variables and expected signs in probability models.

\begin{tabular}{|c|c|c|c|}
\hline \multicolumn{2}{|r|}{ VARIABLE } & DESCRIPTION & SIGN \\
\hline \multirow{4}{*}{ |. } & Elementary & $\begin{array}{l}\text { A binary variable that takes the value of one if he/she has elementary } \\
\text { school, zero if he/she has a university degree }\end{array}$ & + \\
\hline & High School & $\begin{array}{l}\text { A binary variable that takes the value of one if he/she has a bachelor's } \\
\text { degree, zero if he/she has a university degree }\end{array}$ & + \\
\hline & $\begin{array}{r}\text { Technical- } \\
\text { Technological }\end{array}$ & $\begin{array}{l}\text { A binary variable that takes the value of one if he/she has technical or } \\
\text { technological studies, zero if he/she has a university degree. }\end{array}$ & + \\
\hline & Age & $\begin{array}{l}\text { Quantitative variable measured in years. It is expected that, the older they } \\
\text { are, the greater the probability of being self-employed. }\end{array}$ & + \\
\hline \multirow{5}{*}{ 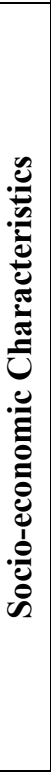 } & Gender & $\begin{array}{l}\text { A binary variable that takes the value of one for men and zero for women. } \\
\text { Men are expected to be more likely to be self-employed workers. }\end{array}$ & + \\
\hline & $\begin{array}{c}\text { Head of the } \\
\text { household }\end{array}$ & $\begin{array}{l}\text { Takes the value of one, if he/she is the head of the household, zero if he/she } \\
\text { is not. As he/she has the responsibility of sustaining a household, and given } \\
\text { labor instability of a self-employed worker, a negative marginal effect is } \\
\text { expected. }\end{array}$ & - \\
\hline & Marital status* & $\begin{array}{l}\text { Takes the value of one if he/she is committed and zero if not. The expected } \\
\text { sign is negative. Given marital responsibility, the individual will want to } \\
\text { maintain job stability by being employed. }\end{array}$ & - \\
\hline & $\begin{array}{r}\text { Information and } \\
\text { communications } \\
\text { technology } \\
(I C T s)\end{array}$ & $\begin{array}{l}\text { Takes the value of one if he/she has access to internet, and at least to one } \\
\text { computer, zero if he/she does not. It is considered that access to internet and } \\
\text { a computer, reduces the opportunity costs of misinformation, so the } \\
\text { individual is better informed and knows more of the state of the labor } \\
\text { market, and in this way, he reduces the time spent to job search. As a result, } \\
\text { the expected marginal effect is negative. }\end{array}$ & - \\
\hline & $\begin{array}{r}\text { Unemployment } \\
\text { duration }\end{array}$ & $\begin{array}{l}\text { Answers the question for how long have you been looking for work? if } \\
\text { he/she declare not to be engaged in formal jobs. A quantitative variable } \\
\text { measured in months. The longer the individual is unemployed, the greater } \\
\text { the probability of being in self-employment. }\end{array}$ & + \\
\hline \multirow{2}{*}{ 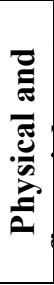 } & $\begin{array}{r}\text { Own residential } \\
\text { property }\end{array}$ & $\begin{array}{l}\text { Takes the value of one, if he/she has its own house without a mortgage } \\
\text { credit and zero, if he/she does not. The expected marginal effect is positive, } \\
\text { since not paying rent gives more leniency and greater possibilities of } \\
\text { undertaking a business venture of their own. }\end{array}$ & + \\
\hline & $\begin{array}{r}\text { Other own } \\
\text { buildings }\end{array}$ & $\begin{array}{l}\text { Takes the value of one if he/she has own buildings. He/she can take } \\
\text { advantage of these assets to start his own business, so a positive sign is } \\
\text { expected. }\end{array}$ & + \\
\hline
\end{tabular}




\begin{tabular}{|c|l|l|l} 
Own vehicle & $\begin{array}{l}\text { Takes the value of one if he/she has his own vehicle and zero, if he/she does } \\
\text { not. The expected sign is positive, given that in case of eventual loss of } \\
\text { employment, owning a vehicle can become an asset to generating income on } \\
\text { its own. }\end{array}$ \\
\hline $\begin{array}{c}\text { Other means of } \\
\text { transportation }\end{array}$ & $\begin{array}{l}\text { Takes the value of one if he/she owns taxis, buses, vans, trucks, etc., and } \\
\text { otherwise, zero. A positive sign is expected between the probability of being } \\
\text { an own-account worker and being the owner of (the possessions of the } \\
\text { household) this kind of means of transportation. }\end{array}$ & + \\
\hline Access to credit & $\begin{array}{l}\text { Takes the value of one if he/she has access to credit and zero, if he/she does } \\
\text { not. Access to credit improves the conditions of initial liquidity to undertake } \\
\text { a sole propertiorship business unit; therefore, the expected marginal effect is } \\
\text { positive. }\end{array}$ & + \\
\hline
\end{tabular}

*Engaged has been defined as the person who is married or currently living with his or her partner. Source: Authors' elaboration.

\subsection{Econometric models.}

As previously mentioned, two models will be estimated in this work. The purpose with the first one is to determine which are the aspects that affect the choice of being an own-account worker (formal or informal), in relation to the rest of the occupations in the labor market. Therefore, the dependent variable is binary (binomial model). The second model disaggregates own-account workers, for which the dependent variable considers, among other occupations, informal self-employment and formal selfemployment (multinomial model). In line with the developments by Destré and Henrard (2004), Bernhardt (1994) and Rees and Shah (1986), the latent variable model proposed in this study is the following:

$$
\begin{aligned}
y_{j}=\beta_{1}+\beta_{2} \text { Ag }_{j} & +\beta_{3} \text { Elementary }_{j}+\beta_{4} \text { HighSchool }_{j}+\beta_{5} \text { Technical }_{j}+\beta_{6} \text { Gender }_{j} \\
& +\beta_{7} \text { Head }_{j}+\beta_{8} \text { Marital }_{j}+\beta_{9} \text { ITC' }_{j}+\beta_{10} \text { Dur_unemp }_{j}+\beta_{11} \text { Household }_{j} \\
& +\beta_{12} \text { Building }_{j}+\beta_{13} \text { Vehicle }_{j}+\beta_{14} \text { Transportation }_{j}+\beta_{15} \text { Credit }_{j}+\varepsilon_{j}
\end{aligned}
$$

when $y_{j}$ takes the value of 1 , the occupation of the individual will be the one corresponding to the own-account worker (informal or formal); while, when it takes the value of zero, it will indicate another type of work, for instance: private employee, government employee, among others occupations (in "others occupations" were grouped: domestic employee, employer, unpaid worker and day laborer):

$$
y_{j}{ }^{\text {binonomial }}= \begin{cases}1 & \text { if own }- \text { account worker } \\ 0 & \text { if private employee, government employee, others occupatios }\end{cases}
$$

The explanatory variables in equation (1) are described in Table 1. Given the binary nature of the dependent variable, the estimation of (1) cannot be carried out through Ordinary Least Squares. For this reason, the Maximum Likelihood method will be employed, supposing that $\varepsilon_{j} \sim N\left(0, \sigma^{2}=1\right)$, with which an appropriate probit model for discrete choice models must be used, as the one proposed in (1).

However, considering that the general objective of this work is aimed at the identification of the factors that affect the choice of being an informal own-account worker, model (1) will be estimated, although taking as latent variable, the one represented in expression (3):

$$
y_{j}^{\text {multinomial }}=\left\{\begin{array}{l}
\text { Informal own - account } \\
\text { Formal own }- \text { account } \\
\text { Private employee } \\
\text { Government employee } \\
\text { Other occupations }
\end{array}\right.
$$


The probabilities of the options in the labor market will now depend on each of the covariables. This, due to the fact that apart from the alternative of being an informal own-account worker, there are other possibilities such as being a formal own-account worker, self-employed worker, government employee, among other occupations. Taking into consideration that there are several categories of occupations different from informal own-account, the multinomial estimation allows a more consistent approach to the real marginal effects of each of these alternatives on the probability of choosing being an informal own-account worker (Greene, 2012).

However, the choice made by individuals regarding some of the occupational categories, is associated to the comparative advantages, whether they are pecuniary or non-pecuniary, which result from each of them. Therefore, the decision of being a self-employed worker may be biased, more so when the same surveyed individual may define himself in one category or another. Literature defines this situation as self-selection bias, and estimations of the model's coefficients under this bias, produces unbiased estimations, although, inconsistent (Greene, 2012; Wooldridge, 2010). In order to correct the effects of this problem, Heckman $(1979 ; 1976)$ proposed a methodology in which two equations are estimated: one related to participation and the other to interest. In this case, the participation equation will be estimated by means of the probit model as follows:

$$
\begin{gathered}
y_{j}^{\text {Part }}=\gamma_{1}+\gamma_{2} \text { Educ }_{j}+\gamma_{3} \text { Age }_{j}+\gamma_{4} \text { Age }_{j}^{2}+\gamma_{5} \text { Gender }_{j}+\gamma_{6} \text { Head }_{j}+\gamma_{7} \text { Marital }_{j} \\
+\gamma_{8} \text { Household }_{j}+\gamma_{9} \text { Stra }_{j}+\gamma_{10} \text { Stra }_{j}+\gamma_{11} \text { Stra }_{j}+\mu_{j}
\end{gathered}
$$

where $y_{j}^{\text {Part }}$ is the dummy variable, which takes one as a value when the individual participates in the economically active population, and zero if this individual is inactive. Variable Educ represents years of education; which is a recoding of the variables Elementary, High School, TechnicalTechnological and university degree, based on UNESCO's International Standard Classification of Education (ISCED) classification, the variable Age, points out how old the individual $j$ is; variable Gender is dichotomous and contains the category man as a reference; variable Head considers whether the individual is the head of the household; variable Marital indicates whether the individual is engaged; variable Household is dichotomous and indicates whether the person owns a residential property; and finally, Est1, Est2 and Est3 are categorical variables that take one as a value if the individual $\mathrm{j}$ lives in strata 1, 2 or 3; otherwise, they take zero as a value if the reference category is strata 4,5 or 6 (The purpose of grouping strata 4, 5 and 6 together was to maintain the same analysis format of both surveys, GISH and CLS. This is also related to the limited available information in high strata).

It is worth mentioning that in econometrical terms, the methodology by Heckman can be applied in only one stage, through the optimization process of the likelihood function, which involves both the interest equation and the participation equation (Greene, 2012). Thus, equations (1) and (4) produce $\varepsilon_{j}$ and $\mu_{\mathrm{j}}$, which are the stocastic perturbations of the sample values $y_{j}$, which are normally distributed with a mean of zero and constant variance; in addition, $\operatorname{corr}(\mu, \varepsilon)=\rho$, in which if $\rho \neq 0$, it is valid to correct for selection bias.

It is worth highlighting that, among the applications carried out for Colombia, this work stands out from the rest when correcting self-selection bias in the moment of estimating the choice equations, which represents an important contribution to empirical literature.

Finally, the matrix of variance and covariance of the estimated coefficients proposed by White (1980), was employed in all estimations, with the aim at obtaining robust estimators that would allow the statistical inference (hypothesis test) to be carried out properly. White's methodology is quite useful for cross-sectional data, such as that found in the GISH and CLS, given the presence of heteroscedasticity. 


\section{Results.}

\subsection{Descriptive analysis.}

For the years 2001-2015, the average global participation rate in Colombia was $63.0 \%$. Its behavior along this period was highly fluctuating. For this same period, the average occupation rate was $55.0 \%$, and the unemployment rate showed a decreasing tendency along the period (see Graph 1, panel A). On the other hand, participation of own-account workers in the labor market in Colombia was greater than $35.0 \%$, and exceeded participation of particular employee, except for 2007 (see Graph 1, panel B). According to Suárez (2020), in 2019, the proportion of own-account workers continues to be higher than that of private employees. When calculating the correlation coefficient between occupations, it was estimated that among own-account workers and particular employee, the aforementioned coefficient was 0.23 , and for the other occupations, was -0.71 , which indicates a counter cyclical behavior in the Colombian labor market.

Graph 1. Main indicators of the labor market in Colombia: 2001-2015.

Panel A. Overall Rate of Participation, Occupation rate and Unemployment Rate Panel B. Occupational position

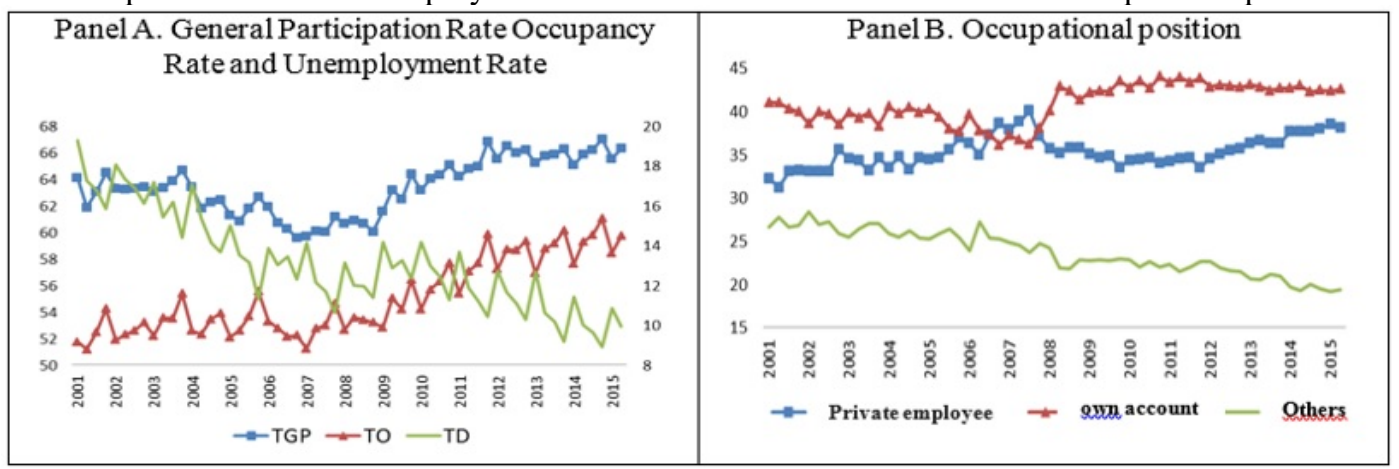

Note: Government employees, domestic workers, employers, unpaid employees and day employees are grouped together in "Others".

Source: Authors' elaboration based on data from the GISH, 2001-2015.

An analysis of transitions between stages of the labor market for the same individuals in two periods, 2010 and 2013, allows visualizing the previous statement. Of own-account workers in 2010, $61.0 \%$ continued being in that position in $2013 ; 13 \%$ changed their status to self-employed workers and $13.0 \%$ changed theirs to inactivity. Nevertheless, from the employers in $2010,52.0 \%$ changed their status to own-account workers in 2013. In the same way, $43.0 \%$ of unpaid workers and $28.0 \%$ of unemployed workers in 2013 became self-employed workers (Table 2). This indicates that selfemployment represents an important alternative to generate income in Colombia. This first result agrees with findings by Santa María et al. (2009). These authors used the Household Survey for the periods 1996, 2000 and 2006, and concluded that the greatest transition was found in own-account workers and employers. 
Table 2. Transitions between occupations in the Colombian labor market, 2010 and 2013.

\begin{tabular}{r|c|c|c|c|c|c|c|c|c}
\hline \multirow{2}{*}{$\begin{array}{c}\text { Work in } \\
2010\end{array}$} & $\begin{array}{c}\text { Own- } \\
\text { account }\end{array}$ & $\begin{array}{c}\text { Private } \\
\text { employee }\end{array}$ & Government & $\begin{array}{c}\text { Day } \\
\text { employee }\end{array}$ & Domestic & Employer & $\begin{array}{c}\text { Unpaid } \\
\text { work }\end{array}$ & Unemployed & Inactive \\
\hline $\begin{array}{c}\text { Own- } \\
\text { account }\end{array}$ & $61.0 \%$ & $13.0 \%$ & $2.0 \%$ & $2.0 \%$ & $2.0 \%$ & $3.0 \%$ & $1.0 \%$ & $4.0 \%$ & $13.0 \%$ \\
\hline $\begin{array}{c}\text { Private } \\
\text { employee }\end{array}$ & $16.0 \%$ & $64.0 \%$ & $5.0 \%$ & $1.0 \%$ & $2.0 \%$ & $1.0 \%$ & $1.0 \%$ & $4.0 \%$ & $6.0 \%$ \\
\hline Government & $7.0 \%$ & $12.0 \%$ & $72.0 \%$ & $0.4 \%$ & & $0.4 \%$ & $1.0 \%$ & $2.0 \%$ & $5.0 \%$ \\
\hline $\begin{array}{c}\text { Day } \\
\text { employee }\end{array}$ & $27.0 \%$ & $16.0 \%$ & $2.0 \%$ & $38.0 \%$ & $2.0 \%$ & $2.0 \%$ & & $5.0 \%$ & $8.0 \%$ \\
\hline Domestic & $27.0 \%$ & $13.0 \%$ & $1.0 \%$ & & $32.0 \%$ & & $1.0 \%$ & $6.0 \%$ & $19.0 \%$ \\
\hline Employer & $52.0 \%$ & $15.0 \%$ & $3.0 \%$ & $2.0 \%$ & $1.0 \%$ & $18.0 \%$ & $1.0 \%$ & $4.0 \%$ & $6.0 \%$ \\
\hline $\begin{array}{r}\text { Unpaid } \\
\text { work }\end{array}$ & $43.0 \%$ & $11.0 \%$ & $1.0 \%$ & $1.0 \%$ & $1.0 \%$ & $2.0 \%$ & $9.0 \%$ & $4.0 \%$ & $29.0 \%$ \\
\hline Unemployed & $28.0 \%$ & $24.0 \%$ & $2.0 \%$ & $2.0 \%$ & $5.0 \%$ & & $1.0 \%$ & $14.0 \%$ & $25.0 \%$ \\
\hline Inactive & $19.0 \%$ & $25.0 \%$ & $3.0 \%$ & $1.0 \%$ & $2.0 \%$ & $0.3 \%$ & $1.0 \%$ & $9.0 \%$ & $38.0 \%$ \\
\hline
\end{tabular}

Source: Authors' calculations based on data from CLS.

Now, considering that the occupation rate was relatively stable from 2010 to 2015 (see Graph 1, panel B), it can be inferred that the reduction of the number of own-account workers was compensated by the number of people who changed their status from employers, unpaid workers and unemployed people to formal and informal own-account workers.

In relation to the motivations why individuals opted for own-account work in 2010, the main reason was not finding a job as a wage-earner. This is an unusual finding, inasmuch as the Colombian economy had been in a recovery period, with an average growth of $4.0 \%$ since 2008 . By 2013 , while this reason is less significant in relation to the rest of them, it continued to be the most important cause of own-account work in Colombia. Being their own boss and earning a higher income represented the second and third causes, respectively (Graph 2).

Graph 2. Reasons that people are own-account workers in Colombia, 2010 and 2013.

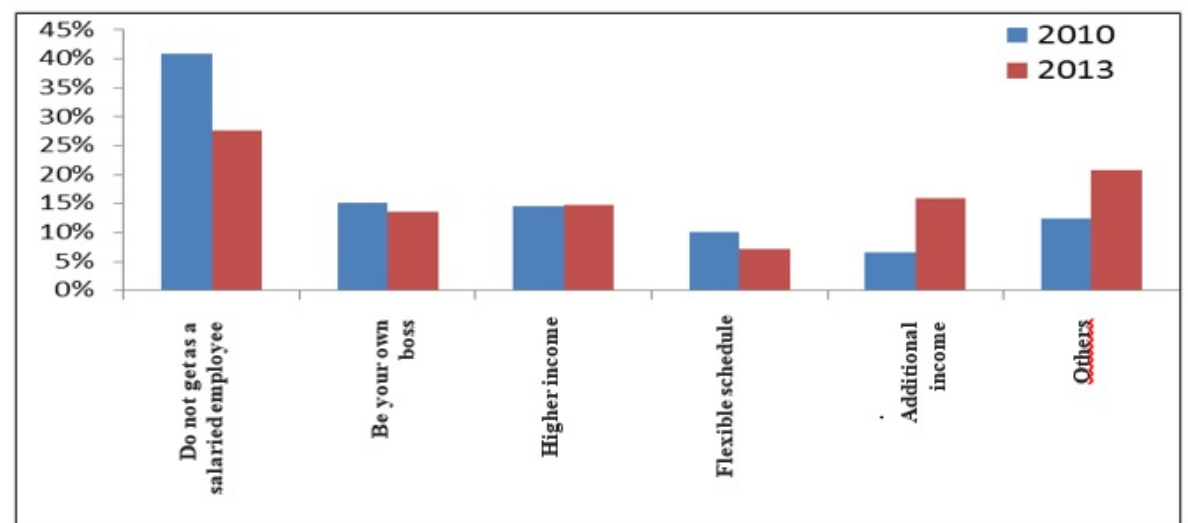

Source: Authors' calculations based on data from CLS.

Some of the characteristics of the employed population in Colombia for 2010 and 2013 are presented in Table 3. As can be seen, own-account workers had in average, less years of education, compared to private employee and other occupations. Additionally, they were the oldest, most of them were the head of the household, and were engaged and belonged to low-medium socio-economic strata. 
Table 3. Characteristics of employed people in Colombia, 2010 and 2013.

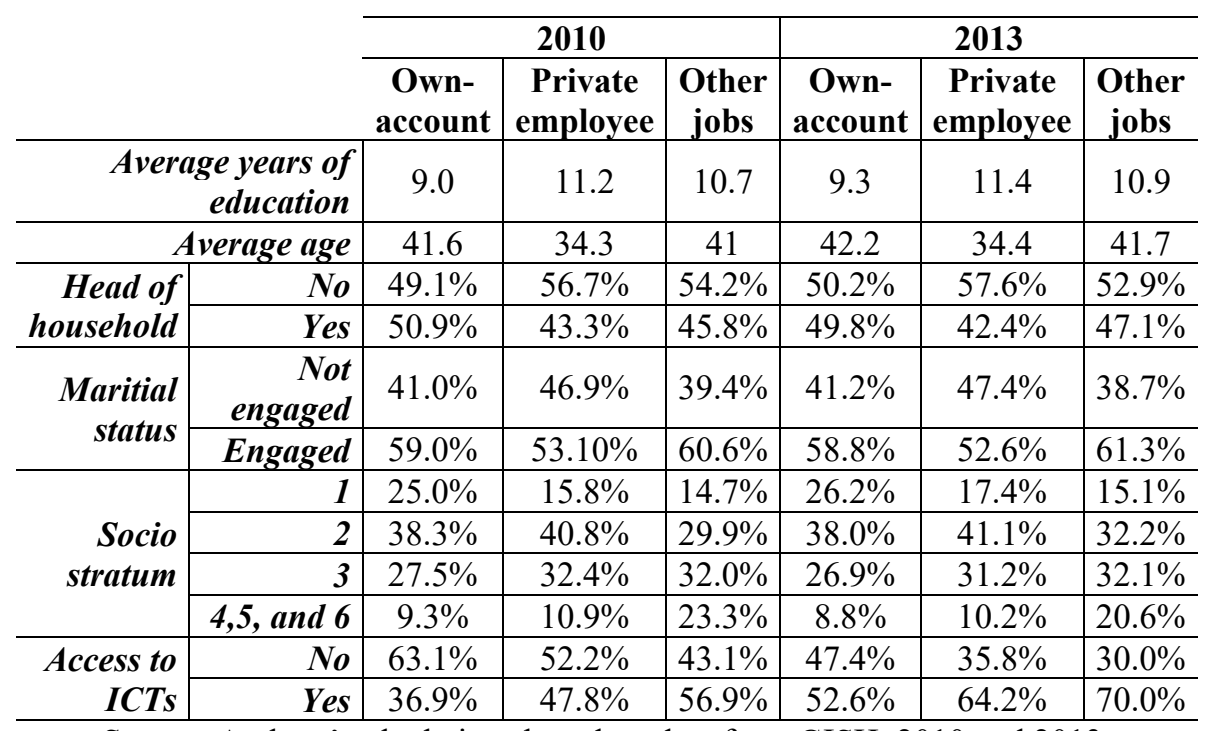

Source: Authors' calculations based on data from GISH, 2010 and 2013.

It is important to highlight the significant increase of the access to ICT's by employed people in Colombia, due to penetration policies that the national government had been applying, through the Minister of Communications. From the perspective of physical and financial assets, in Colombia, most employed people did not own a house, much less, other type of buildings. Likewise, they did not own an automobile, or any transportation equipment, and most of the workers did not have access to credit. Among those who did, they used this credit to acquire goods or services for consumption. It is worth mentioning that the proportion of workers that allocated credit for business assets was higher in the case of own-account workers (Table 4).

Table 4. Characterization of physical and financial assets for employed people in Colombia, 2010 and 2013.

\begin{tabular}{|c|c|c|c|c|c|c|c|}
\hline & & \multirow{2}{*}{\multicolumn{3}{|c|}{$\frac{2013 .}{2010}$}} & \multirow{2}{*}{\multicolumn{3}{|c|}{2013}} \\
\hline & & & & & & & \\
\hline & & $\begin{array}{c}\text { Own- } \\
\text { account }\end{array}$ & $\begin{array}{c}\text { Private } \\
\text { employee }\end{array}$ & $\begin{array}{c}\text { Other } \\
\text { jobs }\end{array}$ & \multirow{2}{*}{$\begin{array}{c}\begin{array}{c}\text { Own- } \\
\text { account }\end{array} \\
52.20 \% \\
\end{array}$} & \multirow{2}{*}{$\begin{array}{r}\begin{array}{c}\text { Private } \\
\text { employee }\end{array} \\
59.70 \%\end{array}$} & \multirow{2}{*}{$\begin{array}{c}\begin{array}{c}\text { Other } \\
\text { jobs }\end{array} \\
50.20 \%\end{array}$} \\
\hline Own residential & No & $61.40 \%$ & $62.10 \%$ & $67.40 \%$ & & & \\
\hline property & Yes & $38.60 \%$ & $37.90 \%$ & $32.60 \%$ & $47.80 \%$ & $40.30 \%$ & $49.80 \%$ \\
\hline \multirow{2}{*}{ Other buildings } & No & $95.60 \%$ & $94.50 \%$ & $90.00 \%$ & $91.00 \%$ & $92.50 \%$ & $88.30 \%$ \\
\hline & Yes & $4.40 \%$ & $5.50 \%$ & $10.00 \%$ & $9.00 \%$ & $7.50 \%$ & $11.70 \%$ \\
\hline \multirow{2}{*}{ Own vehicle } & No & $84.30 \%$ & $82.40 \%$ & $81.30 \%$ & $83.80 \%$ & $81.20 \%$ & $70.60 \%$ \\
\hline & Yes & $15.70 \%$ & $17.60 \%$ & $18.70 \%$ & $16.20 \%$ & $18.80 \%$ & $29.40 \%$ \\
\hline \multirow{2}{*}{$\begin{array}{r}\text { Transportation } \\
\text { equipment }\end{array}$} & No & $98.80 \%$ & $99.70 \%$ & $99.40 \%$ & $96.00 \%$ & $98.00 \%$ & $99.40 \%$ \\
\hline & Yes & $1.20 \%$ & $0.30 \%$ & $0.60 \%$ & $4.00 \%$ & $2.00 \%$ & $0.60 \%$ \\
\hline \multirow{2}{*}{ Access to credit } & No & $55.30 \%$ & $45.40 \%$ & $52.70 \%$ & $48.30 \%$ & $39.20 \%$ & $37.50 \%$ \\
\hline & Yes & $44.70 \%$ & $54.60 \%$ & $47.30 \%$ & $51.70 \%$ & $60.80 \%$ & $62.50 \%$ \\
\hline \multirow{7}{*}{$\begin{array}{r}\text { Purpose of } \\
\text { credit }\end{array}$} & $\begin{array}{c}\text { Assets for the } \\
\text { business }\end{array}$ & $18.80 \%$ & $6.30 \%$ & $11.70 \%$ & $19.30 \%$ & $14.40 \%$ & $19.90 \%$ \\
\hline & Residential property & $18.10 \%$ & $30.10 \%$ & $15.90 \%$ & $15.70 \%$ & $14.50 \%$ & $10.70 \%$ \\
\hline & $\begin{array}{r}\text { Health. education } \\
\text { and recreation }\end{array}$ & $5.30 \%$ & $6.50 \%$ & $7.70 \%$ & $14.00 \%$ & $8.90 \%$ & $10.00 \%$ \\
\hline & Consumer goods & $22.40 \%$ & $22.20 \%$ & $17.70 \%$ & $23.60 \%$ & $32.20 \%$ & $22.50 \%$ \\
\hline & Vehicle & $5.50 \%$ & $6.90 \%$ & $7.60 \%$ & $5.80 \%$ & $6.30 \%$ & $6.60 \%$ \\
\hline & Payment other debts & $8.70 \%$ & $8.10 \%$ & $6.30 \%$ & $18.50 \%$ & $19.00 \%$ & $26.50 \%$ \\
\hline & Other & $21.10 \%$ & $19.90 \%$ & $33.20 \%$ & $3.00 \%$ & $4.70 \%$ & $3.70 \%$ \\
\hline
\end{tabular}

Source: Authors' calculations based on data from GISH, 2010 and 2013. 
When characterizing own-account workers, considering whether they were formal or informal, results show that among employed people over sixty years old on average, these were mostly informal. For people between eighteen and forty years old, most of them were formal workers and secondly, selfemployed workers. From the point of view of education, the camel's hump phenomenon took place; approximately in the fifth, eleventh and sixteenth years of education, given the completion of levels of studies and having obtained a degree or diploma. However, a proportion of the individuals did not continue their studies towards superior levels. Graph 3 shows that for 2010 and 2013, the majority of informal own-account workers were informal; around five years of education or elementary were accumulated. Meanwhile, accumulation of years of education for particular employee was approximately eleven years (high school), and most of formal own-account workers, had studied at the university level (see Annex 1).

\section{Graph 3. Age and education distribution for employed people in Colombia, 2010 and 2013.}
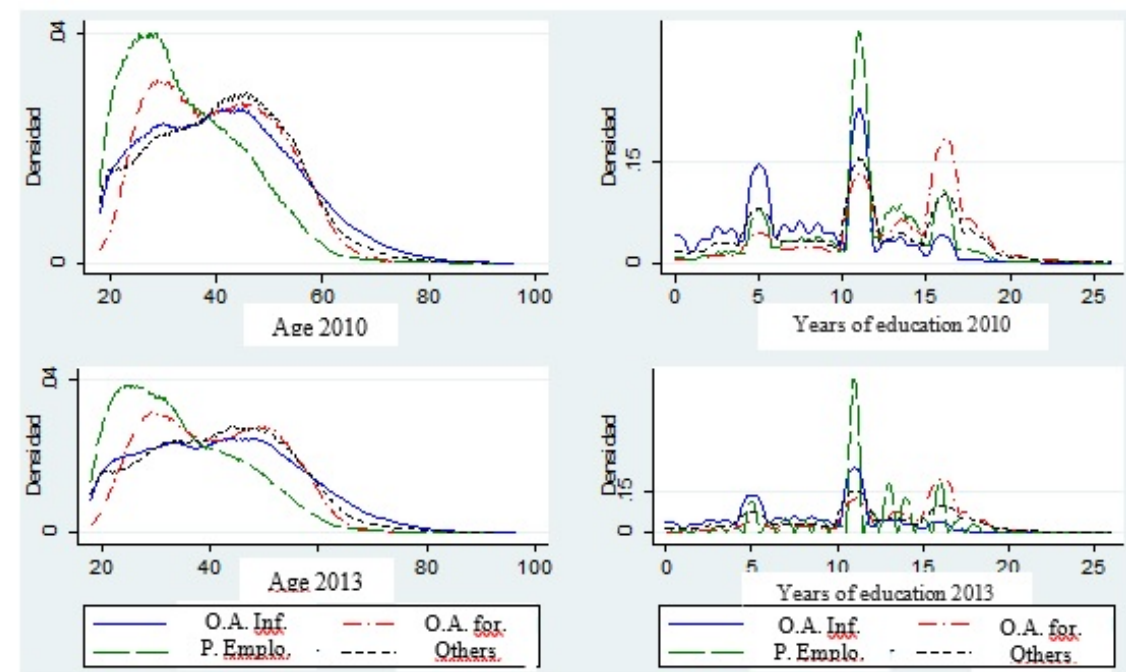

Source: Authors' calculations and elaboration based on data from GISH, 2010 and 2013.

Regarding to the participation of own-account workers by branch of economic activity, Graph 4 shows that for the years of study, a high proportion of formal workers belonged to the service sector; followed by real estate-related activities and trade. Meanwhile, informal workers were concentrated in the trade sector, followed by the sectors of services and transportation. These sectors generated, on average, $68.0 \%$ of informal employment. Mondragón and Peña (2010) revealed similar results by studying the period 1984-2006. This suggests that the informal own-account worker was located in sectors of easy access in order to generate income, and required low human and physical capital, such as those that consist of neighborhood stores, street kiosks, driving vehicles and other activities which represent a null value generation. This is based in the argument by Blanchflower and Shadforth (2007). The authors mention that there is a higher probability of being an own-account worker in the sectors in which less education is required.

Our results provide evidence of the above. For formal own-account workers, the proportion of formal workers in the service sector is 2.68 times greater than the proportion of workers in the commerce sector $(41.5 \%$ and $15.5 \%$, respectively). For informal own-account workers, the proportion of informal workers who are located in the commerce sector is 2.72 times higher than the informal workers who are only employed in the service sector (39.5\% and $14.5 \%$ respectively). Therefore, the service sector has a greater barrier to access: educational level, since the educational level of formal own-account workers is, on average, university level (Graph 4). 
Graph 4. Participation of own-account workers by economic sector in Colombia, 2010 and 2013.

Panel A. Formal

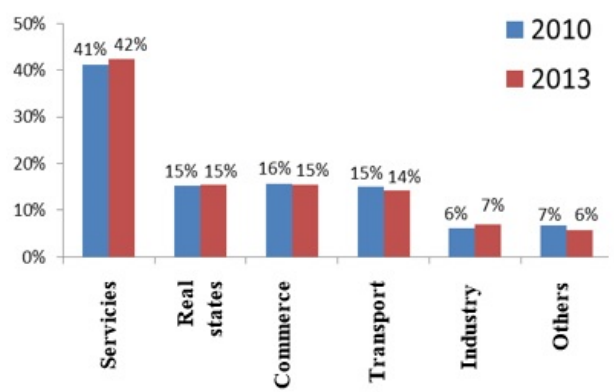

Panel B. Informal

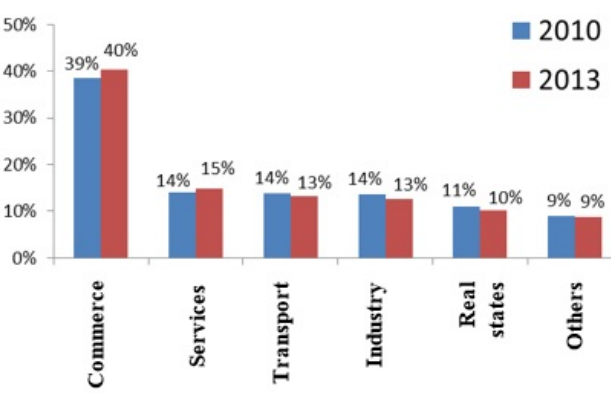

Source: Authors' calculations and elaboration based on data from GISH, 2010 and 2013.

Lastly, and considering a highly relevant factor, Table 5 shows the duration of unemployment of workers before they became own-account workers. As can be seen, the duration of unemployment, for both 2010 and 2013, was greater for those informal workers. This suggests that there was a "resistance" to informal own-account work within the individual, therefore, the individual prefers unemployment to informal own-account work.

Table 5. Duration of unemployment, before being an own-account worker in Colombia, 2010 and 2013 (months).

\begin{tabular}{|c|c|c|c|c|}
\hline & \multicolumn{2}{|c|}{ Formal } & \multicolumn{2}{|c|}{ Informal } \\
\hline & 2010 & 2013 & 2010 & 2013 \\
\hline Private company employee & 6 & 5 & 8 & 7 \\
\hline Government employee & 8 & 5 & 9 & 7 \\
\hline Domestic employee & 7 & 6 & 11 & 10 \\
\hline Employer & 4 & 4 & 7 & 5 \\
\hline Day employee & 3 & 5 & 5 & 4 \\
\hline Average & 7 & 5 & 8 & 7 \\
\hline
\end{tabular}

Source: authors' calculations and elaboration based on data from GISH, 2010 and 2013.

On the other hand, when employing the Kaplan-Meier survival function (1958) to the duration of unemployment of own-account workers, it became evident that people who finally decided to find a job as self-employed workers, were more rapidly employed in formal self-employment. This is probably due to the fact that most of these people were professionals, and the market values more independent work of qualified people than from those who are not (Graph 5). 

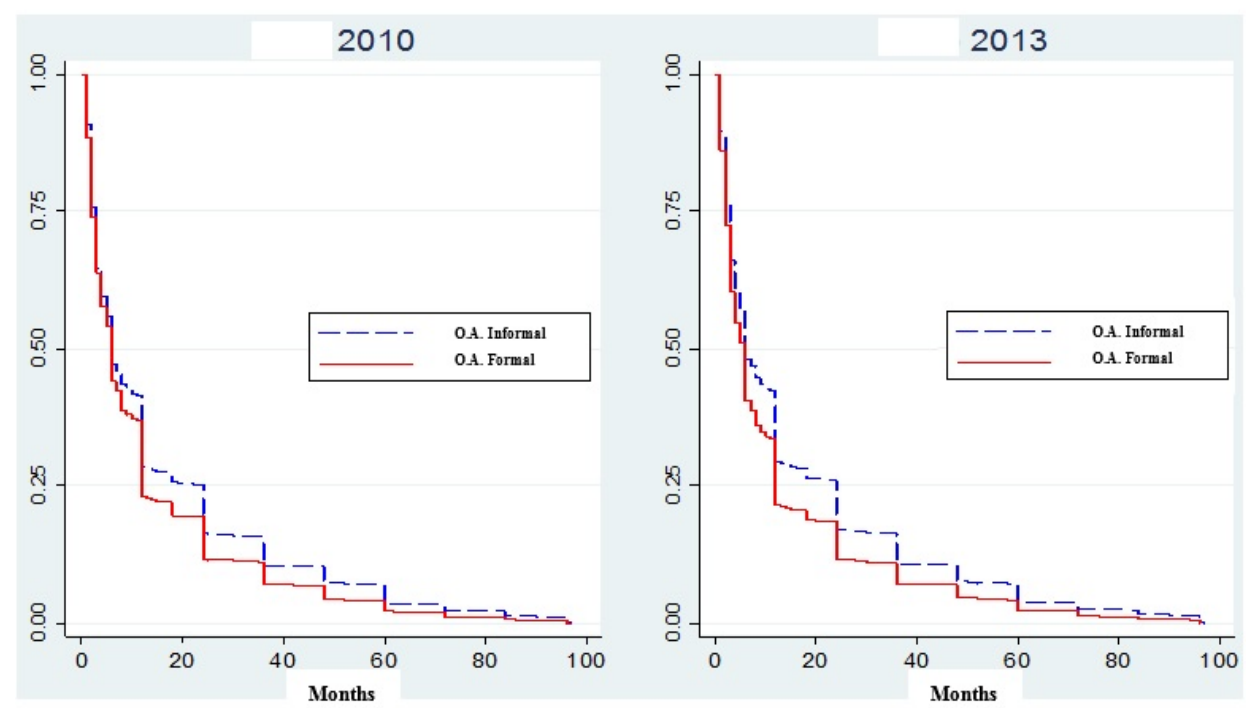

Source: Authors' calculations and elaboration based on data from GISH, 2010 and 2013.

\subsection{Empirical results.}

Evidence of the empirical contrast carried out in this work is presented as follows. The estimations of the models are corrected for selection bias (see Annex 2). The interpretation of the results of the estimations of the binomial (marginal effects) (Table 6) and multinomial (Tables 7 and 8) models are presented as well. These models allow to empirically validate which were the main aspects that affected the possibility of being an own-account worker in Colombia, for 2010 and 2013.

\subsubsection{Estimation of the binomial model}

Results obtained from data from GISH and CLS were similar. Among the variables that significantly affected human capital, age and educational level, were factors that directly and significantly affected the probability of being an own-account worker. Specifically, the impact of a higher educational level on this probability was increasingly lower: an individual with elementary studies had a probability being in own-account worker; which was $35.7 \%$ higher in relation to an individual with a university degree. Meanwhile, in the case of an individual with technological studies, this probability was $20.0 \%$ higher, which represents a coherent result to that found by Destré and Henrard (2004) and Evans and Jovanovic (1989) for Colombia, when considering the level of studies by years of education (Table 6)

Among socio-economic characteristics, a positive effect related to gender and unemployment duration was calculated. This is: a) men had a greater possibility of being own-account workers, in relation to women, which leads to inferring that the reserved salary of women might have been higher than that of men; this resulted in a greater resistance by women to become own-account workers, with the intention of finding a better job; b) an additional month in unemployment increased the probability of undertaking his own business venture, which corresponds to the estimations by Meager (1992) and Bogenhold and Staber (1991). The coefficients associated to unemployment duration with data from CLS were not estimated, given that according to the survey, by 2013, the variable did not gather enough information as to analyze informality and the labor situation of the employee; and, no additional relevant data were given to 2010 (see the document Cambios en cuestionarios, 2013, p. 61, CLS). 
Table 6. Marginal effects on the probability of being an own-account worker in Colombia, 2010 and 2013.

\begin{tabular}{|c|c|c|c|c|c|}
\hline \multirow{2}{*}{\multicolumn{2}{|c|}{ Variable }} & \multicolumn{2}{|c|}{ GISH } & \multicolumn{2}{|c|}{ CLS } \\
\hline & & 2010 & 2013 & 2010 & 2013 \\
\hline \multirow{4}{*}{ 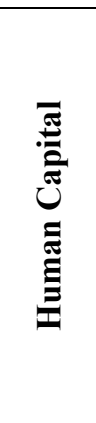 } & Age & $\begin{array}{c}0,633 * * * \\
(0,002)\end{array}$ & $\begin{array}{c}0,648 * * * \\
(0,002)\end{array}$ & $\begin{array}{c}0,604 * * * \\
(0,002)\end{array}$ & $\begin{array}{c}0,555 * * * \\
(0,002)\end{array}$ \\
\hline & Elementary & $\begin{array}{c}35,785^{* * *} \\
(0,001)\end{array}$ & $\begin{array}{c}32,88 * * * \\
(0,001)\end{array}$ & $\begin{array}{c}31,863 * * * \\
(0,098)\end{array}$ & $\begin{array}{c}41,153 * * * \\
(0,084)\end{array}$ \\
\hline & High school & $\begin{array}{c}23,38 * * * \\
(0,008)\end{array}$ & $\begin{array}{c}21,822 * * * \\
(0,009)\end{array}$ & $\begin{array}{c}25,425 * * * \\
(0,094)\end{array}$ & $\begin{array}{c}28,667 * * * \\
(0,079)\end{array}$ \\
\hline & $\begin{array}{r}\text { Technical- } \\
\text { technological }\end{array}$ & $\begin{array}{c}11,672 * * * \\
(0,011)\end{array}$ & $\begin{array}{c}12,108^{* * * *} \\
(0,011)\end{array}$ & $\begin{array}{c}20,001 * * * \\
(0,107)\end{array}$ & $\begin{array}{c}17,501 * * * \\
(0,087)\end{array}$ \\
\hline \multirow{5}{*}{ 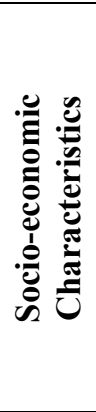 } & Gender & $\begin{array}{c}2,223 * * * \\
(0,006)\end{array}$ & $\begin{array}{c}4,298 * * * \\
(0,007)\end{array}$ & $\begin{array}{l}5,728 * \\
(0,088)\end{array}$ & $\begin{array}{l}-3,156 \\
(0,068)\end{array}$ \\
\hline & Head of household & $\begin{array}{c}-1,548 * * * \\
(0,006)\end{array}$ & $\begin{array}{c}-0,881 * * \\
(0,007)\end{array}$ & $\begin{array}{l}-1,379 \\
(0,075)\end{array}$ & $\begin{array}{c}-6,069 * * * \\
(0,056)\end{array}$ \\
\hline & Marital status & $\begin{array}{c}1,190 * * * \\
(0,005)\end{array}$ & $\begin{array}{c}0,556 \\
(0,007)\end{array}$ & $\begin{array}{l}9,933 * * \\
(0,079)\end{array}$ & $\begin{array}{c}1,068 \\
(0,049)\end{array}$ \\
\hline & $I C T s$ & $\begin{array}{c}-12,058 * * * \\
(0,006)\end{array}$ & $\begin{array}{c}-11,401 * * * \\
(0,006)\end{array}$ & $\begin{array}{l}-5,041^{*} \\
(0,051)\end{array}$ & $\begin{array}{c}-7,532 * * * \\
(0,045)\end{array}$ \\
\hline & Performance length & $\begin{array}{c}0,311 * * * \\
(0,000) \\
\end{array}$ & $\begin{array}{c}0,263 * * * \\
(0,000) \\
\end{array}$ & & \\
\hline \multirow{6}{*}{ 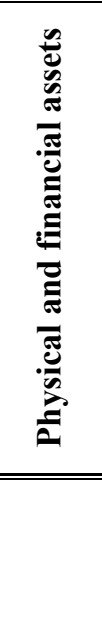 } & $\begin{array}{r}\text { Own residential } \\
\text { property }\end{array}$ & & & $\begin{array}{l}-2,014 \\
(0,049) \\
\end{array}$ & $\begin{array}{l}5,257 * * \\
(0,044)\end{array}$ \\
\hline & Buildings & & & $\begin{array}{c}2,508 \\
(0,098)\end{array}$ & $\begin{array}{c}2792 \\
(0,077) \\
\end{array}$ \\
\hline & Vehicle & & & $\begin{array}{l}6,279 * * \\
(0,069)\end{array}$ & $\begin{array}{c}6,201 * * * \\
(0,061)\end{array}$ \\
\hline & $\begin{array}{r}\text { Means of } \\
\text { transportation }\end{array}$ & & & $\begin{array}{c}22,028 * * \\
(0,249)\end{array}$ & $\begin{array}{c}14,245 * * * \\
(0,124)\end{array}$ \\
\hline & Access to credit & & & $\begin{array}{l}3,001 * \\
(0,047) \\
\end{array}$ & $\begin{array}{c}1270 \\
(0,043) \\
\end{array}$ \\
\hline & $\begin{array}{r}\text { Number of } \\
\text { observations } \\
\text { Wald test } \\
\chi^{2}(\rho=0)\end{array}$ & $\begin{array}{c}361,528 \\
27.011 * * * \\
3,16^{*}\end{array}$ & $\begin{array}{c}313,372 \\
21.020 * * * \\
13,02 * * *\end{array}$ & $\begin{array}{c}4,557 \\
203 * * * \\
8,05 * *\end{array}$ & $\begin{array}{c}5,572 \\
299 * * * \\
5,24 * *\end{array}$ \\
\hline
\end{tabular}

*** Significant at $1 \% ; * * 5 \% ; * 10 \%$.

Note: Marginal effects in percentages. Robust standard errors in parenthesis. $\chi^{2}$ for $\rho=0$, indicates that correcting for selection bias, was in fact, correct.

Source: Authors' calculations based on data from GISH, 2010 and 2013.

Estimations of head of the household and the effect of the ICT's were negative. According to data from the GISH, if the individual was the head of the household, the probability of being an ownaccount worker decreased in $1.54 \%$ for 2010 , and in $0.88 \%$ for 2013 . Regarding ICT's, the estimated relation was exactly the expected, and it was coherent with findings by Aparicio et al. (2013) for Medellín in 2009. Having access to internet or a computer decreased the probability of being ownaccount worker. As a result, having access to information decreased the possibilities of employment and/or reduced the time of searching for employment (Quiñones, 2010; Viáfara \& Uribe, 2009; Uribe \& Gómez, 2004. The effect of marital status was ambiguous; therefore, a general interpretation was not carried out (Table 6).

Results for physical and financial assets were the expected, except for owning a residential property, which for 2010, was negative and non-significant, and for 2013, it was positive. In general, 
having a vehicle, means of transportation (taxi, bus or trucks) and access to credit, increased the probability of being an own-account worker. The greatest impact was presented by means of transportation (increased the probability in $22.0 \%$ in 2010 and $14.2 \%$ in 2013), followed by having a vehicle (grew 6.2\% in 2010 and 2013). Additionally, access to credit with banks and financial institutions increased the probability of self-employment in 3.0\% in 2010. This guarantees a certain liquidity to undertaking sole proprietorship businesses; however, these type of businesses in Colombia do not usually accomplish generating more jobs.

Nevertheless, when analyzing the behavior probability paths of being an own-account worker, controlling for age and educational level, it can be inferred that the probability of being an own-account worker, increased in relation to age augmentation, and it was greater in individuals with an elementary degree, and lower for those with a university degree. Likewise, the difference in terms of probability between these individuals increased in the age range that went from 34 to 66 years old approximately (Graph 6).

\section{Graph 6. Probability paths of self-employment, by educational degree and age, Colombia, 2010 and 2013.}
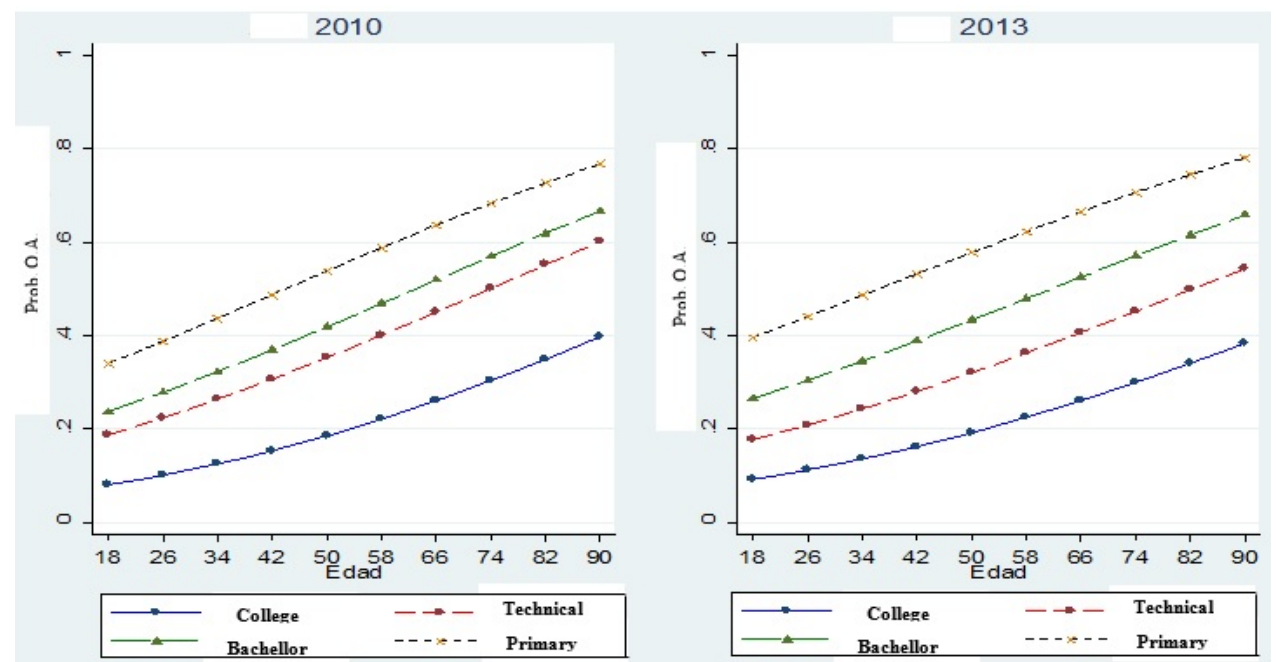

Source: Authors' calculations and elaboration based on data from CLS, 2010 and 2013.

When carrying out the previous exercise, instead controlling by means of the possession of assets, the probability paths indicated that, if an individual with no university degree, but with access to assets, had a greater probability of being an own-account worker, than that who did not. Likewise, this probability increased in relation to age augmentation. This result is indeed logical if taking into account that the Colombian labor market increasingly demands professional and highly qualified professionals (Posso, 2010; Arango et al., 2004). Therefore, a non-professional individual, who possesses physical or financial assets will be highly prone to work on his own. Now, if this individual does not possess any physical or financial assets, while his probability of being in self-employment increases according to age, it is lower in relation to that of the individuals who do possess some sort of assets (Graph 7).

When carrying out the same analysis and comparisons among professional and nonprofessional workers, with physical and financial assets, conclusions were similar: the probability of a being an own-account worker increased with age for graduate people, with or without assets; but the probability was higher for graduate people who possessed both physical and financial assets (Graph 7). 
Graph 7. Probability paths of being an own-account worker according to level of studies reached, access to assets, and age, Colombia, 2010 and 2013.
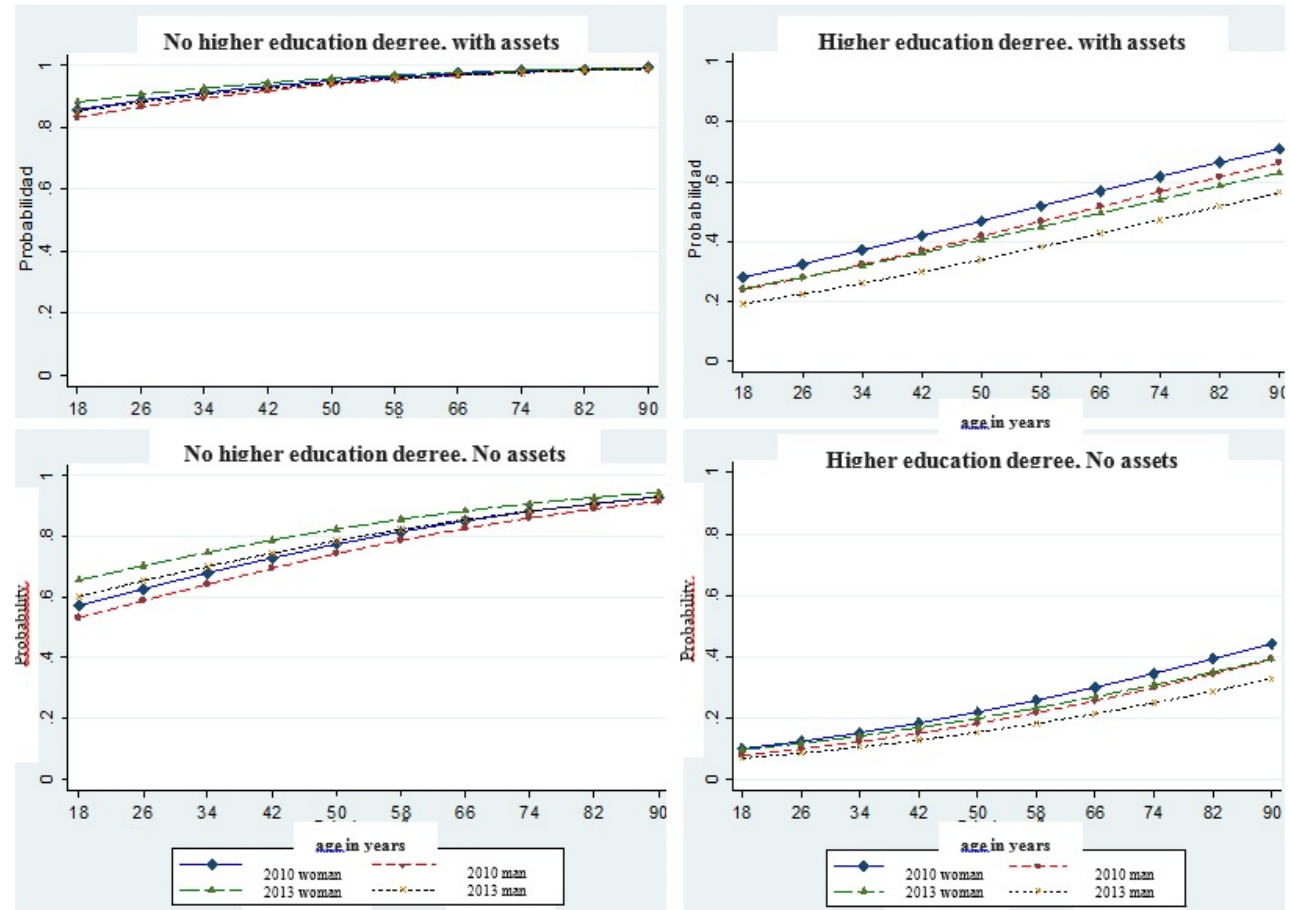

Source: Authors' calculations and elaboration based on data from CLS, 2010 and 2013.

Lastly, when controlling for the probability paths according to the type of asset (means of transportation and access to credit) it becomes evident that as well as in the previous cases, probabilities increased with age. Likewise, the gaps between own-account workers who possessed means of transportation and those who did not, were greater than that gaps or differences between self-employed workers with access to credit and those who did not have access to credit (Graph 8).

Graph 8. Probability paths of being an own-account worker according to assets and age, Colombia, 2010 and 2013.

Panel A. Means of transport

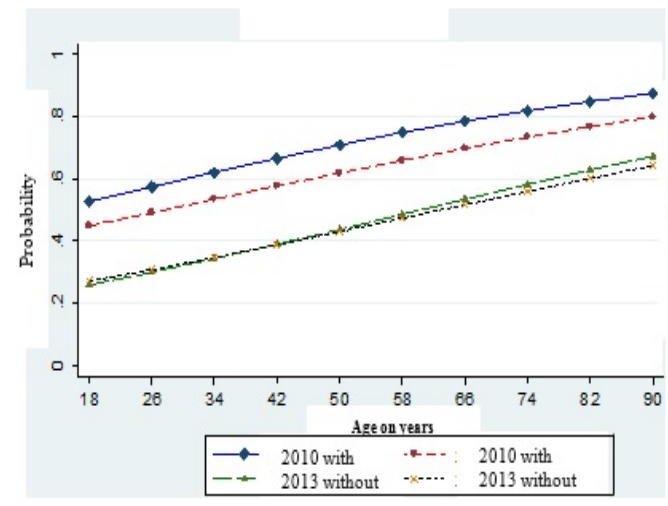

Panel B. Access to credit

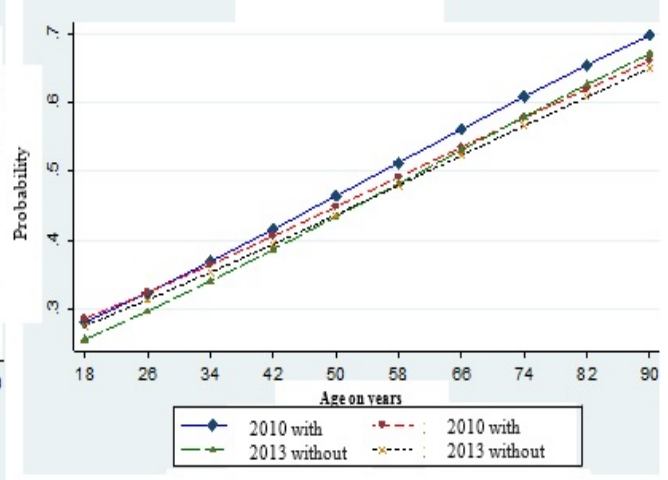

Source: Authors' calculations and elaboration based on data from CLS, 2010 and 2013. 


\subsubsection{Estimation of the multinomial model}

Based on data from the GISH for 2010 and 2013, Table 7 shows the marginal effects (measured in percentages of the variables included in the model) on the probability of being a formal own-account worker, an informal own-account worker, self-employed worker, a government employee and other occupations, Table 8 shows results based on the CLS. In general, findings suggest that both human capital variables and socio-economic characteristics, were factors that determined the probability of all the occupations. However, the effect on it did not only vary with each of the variables, but with the type of occupation:

a) Age decreased the probability of being a particular employee, which indicates that in the Colombian labor market it is harder to find a vacancy as a wage earner to the extent that the individual becomes older. As a consequence, possibilities of becoming an own-account worker increased, especially in informal own-account worker, in which the marginal effect was greater, among the other occupations $(0.61 \%$ and $0.62 \%$, for 2010 and 2013, respectively - GEIH; $0.50 \%$ and $0.77 \%$, for 2010 and 2013 , respectively, CLS).

b) The probability of being an informal own-account worker increased when the individual did not have a university degree, and the impact was greater with only basic studies (elementary, $26.2 \%$ and $29.3 \%$ for 2010 and 2013, respectively, GISH; $28.2 \%$ and $34.7 \%$ for 2010 and 2013 , respectively, CLS), compared to those with a university degree. Nevertheless, the alternatives of being formal own-account worker, of being a particular employee or a government employee decreased if the individual did not possess university studies (Table 7 and Table 8).

c) According to data from the GISH, the effect of gender was significant for all occupations; however, it was not significant for the CLS. Men had a greater possibility of being informal and formal own-account workers in relation to women (positive marginal effect) while the former had greater alternatives of being employed by the government (Table 7). This result suggests that men were more prone to carry out independent work than women; above all, when they are informal own-account worker. Additionally, the proposal on the greater reserve salary for women when it came to decide whether they selected entering into own-account work in relation to men was confirmed.

d) Results for head of household were heterogeneous. On the one hand, according to data from the GISH, its marginal effect (positive), was significant in 2010 but not in 2013. On the other hand, based on data from the CLS, this effect was only significant for informal occupation and particular employee in 2013. Results for marital status were similar. When comparing results from the GISH for 2010 and 2013, there were changes in the parameter's significance, and when comparing the marginal effects between the GISH and the CLS, there was a change in the sign. Taking into account the aforementioned, an interpretation that allows obtaining a general conclusion of these variables on the occupation probability was not carried out. Estimations for the ICT's are coherent with the proposals in this work: they decreased the probability of informal own-account worker, although, it increased formal own-account worker and the possibility of being a particular employee (Table 7 and Table 8).

e) Estimations for unemployment duration and age suggest that when the individual spent more time in unemployment, his possibilities of being a self-employed worker or a government employee decreased. Meanwhile, the probability of being an informal own-account worker increased, in relation to being a formal own-account worker (Table 7). 
Table 7. Marginal effects on main occupations, Colombia, GISH 2010 and 2013.

\begin{tabular}{|c|c|c|c|c|c|c|c|c|c|c|}
\hline \multirow[b]{2}{*}{ Variable } & \multicolumn{5}{|c|}{2010} & \multicolumn{5}{|c|}{2013} \\
\hline & Informal & Formal & $\begin{array}{c}\text { Self- } \\
\text { employed }\end{array}$ & Government & Others & Informal & Formal & $\begin{array}{c}\text { Self- } \\
\text { employed }\end{array}$ & Government & Others \\
\hline Age & $\begin{array}{r}0,613 * * * \\
(0,00012) \\
\end{array}$ & $\begin{array}{r}0,098^{* * *} \\
(0,00005)\end{array}$ & $\begin{array}{r}-0,919 * * * \\
(0,00013)\end{array}$ & $\begin{array}{r}0,101 * * * \\
(0,00003) \\
\end{array}$ & $\begin{array}{l}0,106^{* * * *} \\
(0,00008)\end{array}$ & $\begin{array}{c}0,626^{* * * *} \\
(0,00011) \\
\end{array}$ & $\begin{array}{r}0,120 * * * \\
(0,00005)\end{array}$ & $\begin{array}{r}-0,940 * * * \\
(0,00012)\end{array}$ & $\begin{array}{r}0,083^{* * *} \\
(0,00003) \\
\end{array}$ & $\begin{array}{r}0,111 * * * \\
(0,00006)\end{array}$ \\
\hline Elementary & $\begin{array}{r}26,200 * * * \\
(0,00471) \\
\end{array}$ & $\begin{array}{r}-6,362 * * * \\
(0,00132) \\
\end{array}$ & $\begin{array}{r}-17.906^{* * *} \\
(0,00431) \\
\end{array}$ & $\begin{array}{r}-8,728 * * * \\
(0,00149) \\
\end{array}$ & $\begin{array}{l}6,796^{* * * *} \\
(0,00304) \\
\end{array}$ & $\begin{array}{r}29,360 * * * \\
(0,00452) \\
\end{array}$ & $\begin{array}{r}-7,420 * * * \\
(0,00125) \\
\end{array}$ & $\begin{array}{r}-19,856 * * * \\
(0,00411)\end{array}$ & $\begin{array}{r}-7,487 * * * \\
(0,00125) \\
\end{array}$ & $\begin{array}{l}5,403 * * * \\
(0,00275)\end{array}$ \\
\hline High school & $\begin{array}{r}14,809^{* * *} \\
(0,00490)\end{array}$ & $\begin{array}{r}-844 * * * \\
(0,00104) \\
\end{array}$ & $\begin{array}{r}-7,324 * * * \\
(0,00436)\end{array}$ & $\begin{array}{r}-3,645^{* * *} \\
(0,00086) \\
\end{array}$ & $\begin{array}{l}1,004 * * * \\
(0,00290)\end{array}$ & $\begin{array}{r}18,015^{* * * *} \\
(0,00463) \\
\end{array}$ & $\begin{array}{r}-6,385^{* * *} \\
(0,00108) \\
\end{array}$ & $\begin{array}{r}-9,099 * * * \\
(0,00417) \\
\end{array}$ & $\begin{array}{r}-3,483 * * * \\
(0,00083) \\
\end{array}$ & $\begin{array}{r}0,952 * * * \\
(0,00254)\end{array}$ \\
\hline $\begin{array}{r}\text { Tec. } \\
\text { Tecnological }\end{array}$ & $\begin{array}{l}5,813 * * * \\
(0,00625)\end{array}$ & $\begin{array}{l}-2,522 * * * \\
(0,00082)\end{array}$ & $\begin{array}{r}1,908^{* * *} \\
(0,00570)\end{array}$ & $\begin{array}{r}-1,808 * * * \\
(0,00050)\end{array}$ & $\begin{array}{l}-3,391 * * * \\
(0,00310)\end{array}$ & $\begin{array}{r}8,195 * * * \\
(0,00557)\end{array}$ & $\begin{array}{l}-3,505^{* * *} \\
(0,00079)\end{array}$ & $\begin{array}{r}-0,109 \\
(0,00509)\end{array}$ & $\begin{array}{r}-1.822 * * * \\
(0,00048)\end{array}$ & $\begin{array}{l}-2,758 * * * \\
(0,00259)\end{array}$ \\
\hline Gender & $\begin{array}{c}5,774 * * * \\
(0,00330) \\
\end{array}$ & $\begin{array}{r}0,336^{* * *} \\
(0,00109) \\
\end{array}$ & $\begin{array}{c}2,873 * * * \\
(0,00360) \\
\end{array}$ & $\begin{array}{r}-1,078 * * * \\
(0,00078) \\
\end{array}$ & $\begin{array}{r}-7,904 * * * \\
(0,00193) \\
\end{array}$ & $\begin{array}{c}5,429 * * * \\
(0,00300)\end{array}$ & $\begin{array}{r}0,347 * * * \\
(0,00110) \\
\end{array}$ & $\begin{array}{l}2,505 * * * \\
(0,00324) \\
\end{array}$ & $\begin{array}{r}-0,742 * * * \\
(0,00062) \\
\end{array}$ & $\begin{array}{r}-7,539 * * * \\
(0,00170) \\
\end{array}$ \\
\hline $\begin{array}{r}\text { Head of } \\
\text { household }\end{array}$ & $\begin{array}{r}1,626 * * * \\
(0,00314) \\
\end{array}$ & $\begin{array}{r}-0,185^{*} \\
(0,00112)\end{array}$ & $\begin{array}{r}-1,906 * * * \\
(0,00326)\end{array}$ & $\begin{array}{r}0,235 * * * \\
(0,00070)\end{array}$ & $\begin{array}{r}0,229 \\
(0,00181) \\
\end{array}$ & $\begin{array}{r}0,389 \\
(0,00285) \\
\end{array}$ & $\begin{array}{r}-0,085 \\
(0,00109) \\
\end{array}$ & $\begin{array}{c}-0,711 * * \\
(0,00297)\end{array}$ & $\begin{array}{r}0,355^{* * * *} \\
(0,00058) \\
\end{array}$ & $\begin{array}{r}0,053 \\
(0,00155) \\
\end{array}$ \\
\hline Marital status & $\begin{array}{r}0,874 * * * \\
(0,00263)\end{array}$ & $\begin{array}{r}-0,479 * * * \\
(0,00095) \\
\end{array}$ & $\begin{array}{r}-1,898 * * * \\
(0,00264) \\
\end{array}$ & $\begin{array}{r}0,285^{*} * * \\
(0,00055) \\
\end{array}$ & $\begin{array}{l}1,218 * * * \\
(0,00155)\end{array}$ & $\begin{array}{r}0,590 * * \\
(0,00247) \\
\end{array}$ & $\begin{array}{r}-0,695 * * * \\
(0,00097) \\
\end{array}$ & $\begin{array}{r}-1,555^{* * *} \\
(0,00250) \\
\end{array}$ & $\begin{array}{r}0,302 * * * \\
(0,00047) \\
\end{array}$ & $\begin{array}{r}1,357 * * * \\
(0,00137)\end{array}$ \\
\hline ICTs & $\begin{array}{r}-11,985 * * * \\
(0,00273)\end{array}$ & $\begin{array}{r}2,394 * * * \\
(0,00119) \\
\end{array}$ & $\begin{array}{r}4,228 * * * \\
(0,00283) \\
\end{array}$ & $\begin{array}{r}0,966^{* * *} \\
(0,00070) \\
\end{array}$ & $\begin{array}{l}4,397 * * * \\
(0,00184) \\
\end{array}$ & $\begin{array}{r}-12,109 * * * \\
(0,00248) \\
\end{array}$ & $\begin{array}{r}2,572 * * * \\
(0,00111) \\
\end{array}$ & $\begin{array}{r}6,205^{* * *} \\
(0,00257) \\
\end{array}$ & $\begin{array}{r}1,201 * * * \\
(0,00064) \\
\end{array}$ & $\begin{array}{r}2,131 * * * \\
(0,00143)\end{array}$ \\
\hline $\begin{array}{r}\text { Unemployment } \\
\text { d. }\end{array}$ & $\begin{array}{l}0.317 * * * \\
(0,00011) \\
\end{array}$ & $\begin{array}{l}0,008 * * * \\
(0,00004)\end{array}$ & $\begin{array}{r}-0,262 * * * \\
(0,00012) \\
\end{array}$ & $\begin{array}{r}-0,013 * * * \\
(0,00002) \\
\end{array}$ & $\begin{array}{r}-0,050 * * * \\
(0,00007) \\
\end{array}$ & $\begin{array}{c}0,273 * * * \\
(0,00010)\end{array}$ & $\begin{array}{r}0,001 \\
(0,00004) \\
\end{array}$ & $\begin{array}{r}-0,253^{* * *} \\
(0,00012) \\
\end{array}$ & $\begin{array}{r}-0,008^{* * *} \\
(0,00002) \\
\end{array}$ & $\begin{array}{r}-0,012 * * \\
(0,00006)\end{array}$ \\
\hline
\end{tabular}

$* * *$ Significant at $1 \% ; * * 5 \% ; * 10 \%$.

Note: Marginal effects in percentages. Robust standard errors in parenthesis.

Source: Authors' calculations based on data from the GISH, 2010 and 2013.

Table 8. Marginal effects on main occupations, Colombia, CLS 2010 and 2013.

\begin{tabular}{|c|c|c|c|c|c|c|c|c|c|c|}
\hline \multirow[t]{2}{*}{ Variable } & \multicolumn{5}{|c|}{2010} & \multicolumn{5}{|c|}{2013} \\
\hline & Informal & Formal & $\begin{array}{c}\text { self- } \\
\text { employed }\end{array}$ & Government & Other & Informal & Formal & $\begin{array}{c}\text { Self- } \\
\text { employed }\end{array}$ & Government & Other \\
\hline Age & $\begin{array}{r}0,508^{* * *} * \\
(0,0011)\end{array}$ & $\begin{array}{r}0,179 * * * \\
(0,0004)\end{array}$ & $\begin{array}{r}-0,674 * * * \\
(0.00115)\end{array}$ & $\begin{array}{r}0,051 \\
(0,0004) \\
\end{array}$ & $\begin{array}{r}-0,065 \\
(0,0006) \\
\end{array}$ & $\begin{array}{r}0,776^{* * *} \\
(0,0012)\end{array}$ & $\begin{array}{r}0.191 * * * \\
(0,0004)\end{array}$ & $\begin{array}{r}-1,114 * * * \\
(0,0012)\end{array}$ & $\begin{array}{r}0,128 * * * \\
(0,0004)\end{array}$ & $\begin{array}{r}0,018 \\
(0,0006)\end{array}$ \\
\hline Elementary & $\begin{array}{r}28,265 * * * \\
(0,0419)\end{array}$ & $\begin{array}{r}-0,309 \\
(0,0087)\end{array}$ & $\begin{array}{r}-21,713 * * * \\
(0.03838)\end{array}$ & $\begin{array}{r}-15,757 * * * \\
(0,0191)\end{array}$ & $\begin{array}{r}9,514 * * * \\
(0,0273)\end{array}$ & $\begin{array}{r}34,714 * * * \\
(0,0375)\end{array}$ & $\begin{array}{r}-0,16 \\
(0,0091)\end{array}$ & $\begin{array}{r}-24,492 * * * \\
(0,03424)\end{array}$ & $\begin{array}{r}-16,151 * * * \\
(0,0132)\end{array}$ & $\begin{array}{r}6,089 * * * \\
(0,0223)\end{array}$ \\
\hline High school & $\begin{array}{r}18,403 * * * \\
(0,0462)\end{array}$ & $\begin{array}{r}-0,826 \\
(0,0083)\end{array}$ & $\begin{array}{r}-16,288 * * * \\
(0,0391)\end{array}$ & $\begin{array}{r}-5,920 * * * \\
(0,0081)\end{array}$ & $\begin{array}{r}4,631 \\
(0,0325) \\
\end{array}$ & $\begin{array}{r}21,815 * * * \\
(0,0394)\end{array}$ & $\begin{array}{r}-0,206 \\
(0,0086)\end{array}$ & $\begin{array}{r}-15,181 * * * \\
(0,0354)\end{array}$ & $\begin{array}{r}-8,824 * * * \\
(0,00913)\end{array}$ & $\begin{array}{r}2,396 \\
(0,0221)\end{array}$ \\
\hline $\begin{array}{r}\text { Tec. } \\
\text { Tecnological }\end{array}$ & $\begin{array}{r}14,997 * * * \\
(0,0526)\end{array}$ & $\begin{array}{r}-0,786 \\
(0.00936)\end{array}$ & $\begin{array}{l}-7,83-1^{*} \\
(0,0463)\end{array}$ & $\begin{array}{r}-3,313 * * * \\
(0,0045)\end{array}$ & $\begin{array}{r}-3,063 \\
(0,0283)\end{array}$ & $\begin{array}{r}12,068 * * * \\
(0,0454)\end{array}$ & $\begin{array}{r}0,473 \\
(0,0107)\end{array}$ & $\begin{array}{r}-4,384 \\
(0,0414)\end{array}$ & $\begin{array}{r}-4,221 * * * \\
(0,00553)\end{array}$ & $\begin{array}{l}-3,936^{* *} \\
(0.02003)\end{array}$ \\
\hline Gender & $\begin{array}{r}9,006^{* *} \\
-(0,0142)\end{array}$ & $\begin{array}{r}0,099 \\
(0,0110)\end{array}$ & $\begin{array}{r}-7,041 \\
(0.04875)\end{array}$ & $\begin{array}{r}-0,173 \\
(0,0146)\end{array}$ & $\begin{array}{r}-1,891 \\
(0,0205)\end{array}$ & $\begin{array}{r}-16,160 * * * \\
(0.02749)\end{array}$ & $\begin{array}{r}-1,493 \\
(0,0098)\end{array}$ & $\begin{array}{r}19,648 * * * \\
(0,0304)\end{array}$ & $\begin{array}{r}1,799^{*} \\
(0.01030)\end{array}$ & $\begin{array}{r}-3.794 * * * \\
(0,0144)\end{array}$ \\
\hline $\begin{array}{r}\text { Head of } \\
\text { household }\end{array}$ & $\begin{array}{r}-0,806 \\
(0,0312) \\
\end{array}$ & $\begin{array}{r}-0,057 \\
(0.01035) \\
\end{array}$ & $\begin{array}{r}2,353 \\
(0,0319) \\
\end{array}$ & $\begin{array}{r}-0,189 \\
(0,0092)\end{array}$ & $\begin{array}{r}-1,301 \\
(0,0168)\end{array}$ & $\begin{array}{r}11,977 * * * \\
(0,0245)\end{array}$ & $\begin{array}{r}0,639 \\
(0,0096) \\
\end{array}$ & $\begin{array}{r}-11,907 * * * \\
(0,0269)\end{array}$ & $\begin{array}{r}-0,685 \\
(0,0098)\end{array}$ & $\begin{array}{r}-0,024 \\
(0,0139)\end{array}$ \\
\hline Marital status & $\begin{array}{r}-12,415 * * * \\
(0,0349) \\
\end{array}$ & $\begin{array}{r}0,134 \\
(0,0094) \\
\end{array}$ & $\begin{array}{r}12,580 * * * \\
(0,0327) \\
\end{array}$ & $\begin{array}{r}0,1 \\
(0,0100) \\
\end{array}$ & $\begin{array}{r}-0,399 \\
(0,0196) \\
\end{array}$ & $\begin{array}{r}15,515 * * * \\
(0,0190) \\
\end{array}$ & $\begin{array}{r}2,254 * * * \\
(0,0061) \\
\end{array}$ & $\begin{array}{r}-14,984 * * * \\
(0,0217) \\
\end{array}$ & $\begin{array}{r}-1,457^{*} \\
(0,0087) \\
\end{array}$ & $\begin{array}{r}-1,327 \\
(0,0123) \\
\end{array}$ \\
\hline$I C T S$ & $\begin{array}{r}-7,335 * * * \\
(0,0209)\end{array}$ & $\begin{array}{r}2,957 * * * \\
(0,0083)\end{array}$ & $\begin{array}{r}8.107 * * * \\
(0,0215) \\
\end{array}$ & $\begin{array}{r}-0,804 \\
(0,0061)\end{array}$ & $\begin{array}{r}-2,926 * * * \\
(0,0109) \\
\end{array}$ & $\begin{array}{r}-8.497 * * * \\
(0,0183) \\
\end{array}$ & $\begin{array}{r}1,228^{*} \\
(0,0064)\end{array}$ & $\begin{array}{r}12,558 * * * \\
(0,0197) \\
\end{array}$ & $\begin{array}{r}-0,872 \\
(0.006 \mathrm{~S} 2) \\
\end{array}$ & $\begin{array}{r}-4,417 * * * \\
(0,0101)\end{array}$ \\
\hline $\begin{array}{r}\text { Own residential } \\
\text { property }\end{array}$ & $\begin{array}{r}-2,708 \\
(0,0205) \\
\end{array}$ & $\begin{array}{r}0,512 \\
(0,0062) \\
\end{array}$ & $\begin{array}{r}2,239 \\
(0.02133) \\
\end{array}$ & $\begin{array}{r}0,606 \\
(0,0059) \\
\end{array}$ & $\begin{array}{r}-0,648 \\
(0,0111) \\
\end{array}$ & $\begin{array}{r}2,037 \\
(0,0183) \\
\end{array}$ & $\begin{array}{r}0,615 \\
(0,0058) \\
\end{array}$ & $\begin{array}{r}-5,563 * * * \\
(0,0193) \\
\end{array}$ & $\begin{array}{r}0,966 \\
(0,0067) \\
\end{array}$ & $\begin{array}{r}1,945^{*} \\
(0,0102) \\
\end{array}$ \\
\hline Buildings & $\begin{array}{r}-1,587 \\
(0,0411) \\
\end{array}$ & $\begin{array}{r}-0,131 \\
(0.00968) \\
\end{array}$ & $\begin{array}{r}-5,709 \\
(0.04063) \\
\end{array}$ & $\begin{array}{r}0,491 \\
(0,0096) \\
\end{array}$ & $\begin{array}{l}6,936 * * \\
(0,0314)\end{array}$ & $\begin{array}{r}-4,063 \\
(0,0306) \\
\end{array}$ & $\begin{array}{r}1,144 \\
(0,0097) \\
\end{array}$ & $\begin{array}{r}-1,082 \\
(0,0342) \\
\end{array}$ & $\begin{array}{r}-0,09 \\
(0.00951) \\
\end{array}$ & $\begin{array}{r}4,089 * \\
(0,0237)\end{array}$ \\
\hline Vehicle & $\begin{array}{r}5.100^{*} \\
(0,0298)\end{array}$ & $\begin{array}{r}1,43 \\
(0,0094) \\
\end{array}$ & $\begin{array}{r}-10,153 * * * \\
(0,0280) \\
\end{array}$ & $\begin{array}{r}-0,954 * \\
(0,0056)\end{array}$ & $\begin{array}{r}4,577 * * \\
(0,0199)\end{array}$ & $\begin{array}{r}6,225 * * \\
(0,0267) \\
\end{array}$ & $\begin{array}{l}2,628 * * * \\
(0,02678) \\
\end{array}$ & $\begin{array}{r}-9,167 * * * \\
(0,0269) \\
\end{array}$ & $\begin{array}{r}-1,004 \\
(0.00696) \\
\end{array}$ & $\begin{array}{r}1,318 \\
(0.01688) \\
\end{array}$ \\
\hline $\begin{array}{r}M . \\
\text { transportation }\end{array}$ & $\begin{array}{r}13,984 \\
(0,1018) \\
\end{array}$ & $\begin{array}{r}11,471 \\
(0,0728) \\
\end{array}$ & $\begin{array}{r}-23,295 * * * \\
(0.07842) \\
\end{array}$ & $\begin{array}{r}-1,588 \\
(0,0161) \\
\end{array}$ & $\begin{array}{r}-0,572 \\
(0,0593) \\
\end{array}$ & $\begin{array}{r}7,802 \\
(0.05551) \\
\end{array}$ & $\begin{array}{r}5,816^{* *} \\
(0,0250) \\
\end{array}$ & $\begin{array}{r}-6,714 \\
(0,0570) \\
\end{array}$ & $\begin{array}{r}-3,151^{* *} \\
(0,0113) \\
\end{array}$ & $\begin{array}{r}-3,754 \\
(0.02544) \\
\end{array}$ \\
\hline Access to credit & $\begin{array}{r}2,973 \\
(0,0191)\end{array}$ & $\begin{array}{r}0,247 \\
(0,0059)\end{array}$ & $\begin{array}{r}-1,397 \\
(0.01930)\end{array}$ & $\begin{array}{r}1,386 * * \\
(0.00571)\end{array}$ & $\begin{array}{r}-3710 * * * \\
(0,0100)\end{array}$ & $\begin{array}{r}1,82 \\
(0,0177)\end{array}$ & $\begin{array}{r}0,151 \\
(0.00572)\end{array}$ & $\begin{array}{r}-2,504 \\
(0,0190)\end{array}$ & $\begin{array}{l}2,423 * * * \\
(0.00704)\end{array}$ & $\begin{array}{r}-1,890^{*} \\
(0,0098)\end{array}$ \\
\hline
\end{tabular}

$* * *$ Significant at $1 \% ; * * 5 \% ; * 10 \%$.

Note: Marginal effects in percentages. Robust standard errors in parenthesis.

Source: Authors' calculations based on data from the CLS, 2010 and 2013.

As mentioned in the beginning of this study, one of its main contributions is including physical and financial assets as a determining factor in the choice of being an own-account worker. The first results that were analyzed with the estimation of the binomial model allowed identifying means of transportation and owning a car, as well as access to credit (2010) as main determining factors of self- 
employment. Now, estimations of the multinomial model specifically allow observing the effect of these assets on the occupations considered in this work. Results confirm that having a car has a more positive and significant effect on informal own-account workers than in formal own-account workers.

\section{Conclusions.}

When carrying out the literature review regarding self-employment, and specifically, when comparing between developed and developing countries, it became evident that own-account work was more vulnerable to creating value. This takes places in developed countries by means of small business units as employers, while in developing countries, including Colombia, the aforementioned workers made up sole proprietorship units, in which income generation depends largely on their individual abilities (see Destré \& Henrard, 2004).

However, results on international studies demonstrate that in general terms, the setting-up of small business units depends to a great extent, to the access to assets and to their liquidity (Blanchflower \& Oswald, 1998; Evans \& Jovanovic, 1989; Lucas, 1978). For the Colombian case, the present work obtains empirical evidence, which is on the same line as the investigations carried out in the international context, based on the information from the ELCA, 2010 and 2013. In particular, it was determined that home ownership, means of transportation and access to credit, are factors that positively and significantly influence the possibility of being an own-account worker. However, when decomposing own-account work into informal and formal, these same factors do not have a significant marginal effect, except for having an automobile, but it is worth mentioning that the expected relationship is equal to that estimated with the model.

On the other hand, when carrying out the characterization of employed people, given an ownaccount context, it was found that they had an educational level of 9.2 years on average, for 2010 and 2013, respectively; the lowest among the other occupations, and presented an average age of $41.9 \%$ : the highest among the rest of them. Among informal workers, $55.5 \%$ of them did not have any educational degree, belonged to economic sectors of easy access and had little capital requirements (businesses and restaurants). While among formal workers, $40.0 \%$ of them had a university degree and were concentrated in the real estate and service sectors as consultants and contractors; which are jobs of higher quality.

Finally, in regards to education as part of human capital, results suggest that the higher the educational level, the lower the probability of being an own-account worker in the Colombian informal sector. Guataquí et al. (2011) who show evidence about the inverse relationship between education and own-account work: the probability of being own-account worker is higher, when the individual has a low educational level. In addition, the authors find that, when the individual remains in own-account work, their income increases when their educational level is higher. These results are similar to those found in the studies that relate self-employment with entrepreneurship (Idrovo et al., 2020; Martínez, Saavedra \& Morones, 2020).

That said, it is important that the government encourages own-account work, trying to "convert" this type of economic activity into an entrepreneurship as such. For this, it must be proposed as state policy support through the training for own-account workers in the management of financial resources and training in business management, in order to achieve the sustainability of these activities in the long term. In addition, it should allow greater access to credit to finance new business ideas, reduce administrative procedures to create new business units and /or allow the transition of existing ones to formal companies, create tax incentives for those that generate employment, improve the availability of technologies, such as accounting platforms, and the formation of human capital, for example, in the management of these platforms. Thus, own-account work will generate a better work environment, and may have a greater impact on the growth and development of the Colombian economy. 


\section{References}

Aparicio, S., Ramírez, H.A., \& Gómez, D.F. (2013). Análisis sobre elección de ocupaciones que generen empleo usando modelos de elección discreta: Medellín Área Metropolitana 2009. Estudios Gerenciales, 29, 476-484. https://doi.org/10.1016/j.estger.2013.11.013.

Arango, L.E., Posada, C.E., \& D.U.J. (2004). Cambios en la Estructura de los Salarios Urbanos en Colombia (1984-2000). Bogotá, Colombia: Borradores de Economía No. 297, Banco de la República.

Bernhardt, I. (1994). Comparative Advantage in Self-employment and Paid work. Canadian Journal of Economics, 27(2), 273-289. https://doi.org/10.2307/135747.

Blanchflower, D.G. (2004). Self-Employment: More May Not Be Better. París: NBER Working Paper Series No. 10286, OCDE. https://doi.org/10.3386/w10286.

Blanchflower, D.G., \& Oswald, A. J. (1998). Entrepreneurship and the Youth Labour Market Problem: a report for the OECD. Paris: OECD.

Blanchflower, D.G., \& Shadforth, C. (2007). Entrepreneurship in the UK. Alemania: Discussion Paper No. 2818 IZA, Institute for the Study of Labor. https://doi.org/10.1561/0300000017.

Bogenhold, D., \& Staber, U. (1991). The decline and rise of self-employment. Work Employment and Society 5(2), 223-239. https://doi.org/10.1177/0950017091005002005.

Bozzoli, C., Brück, T., \& Wald, N. (2011). Self-employment and Conflict in Colombia. Journal of Conflict Resolution, 57(1), 117-142. https://doi.org/10.1177/0022002712464849.

Bradley, J. (2014). Entrepreneurship in an Equilibrium Model of the Labor Market. Scotland: Scottish Institute for Research in Economics, SIRE.

Cain, G.G. (1976). The Challenge of Segmented Labor Market Theories to Orthodox Theory: A Survey. Journal of Economic Literature, 14(4), 1215-1257.

Calvo, G.A., \& Wellisz, S. (1980). Technology, entrepreneurs and firm size. The Quarterly Journal of Economics, 95(4), 663-677. https://doi.org/10.2307/1885486.

Cambios en Cuestionarios (2013). Encuesta Longitudinal Colombiana-ELCA-. Recuperado el 6 de 2018, de https://encuestalongitudinal.uniandes.edu.co/es/datos-elca/2013-ronda-2

Caro, B.L. (1995). Evolución del Sector Informal en Colombia. Plan Nacional para la Microempresa. Corporación para el Desarrollo de la Microempresa. Bogotá: Ministerio de Desarrollo, Departamento Nacional de Planeación.

Destré, G., \& Henrard, V. (2004). The determinants of occupational choice in Colombia: an empirical analysis. Paris: Series Cahiers de la Maison des Sciences Economiques, Université PanthéonSorbonne.

Dickens, W.T., \& Lang, K. (1988). The Reemergence of Segmented Labor Market Theory. The American Economic Review, 78(2), 129-134.

Evans, D.S., \& Jovanovic, B. (1989). An Estimated Model of Entrepreneurial Choice Under Liquidity Constraints. The Journal of Political Economy, 97(4), 808-827. https://doi.org/10.1086/261629 
Evans, D.S., \& Leighton, L.S. (1989). Some Empirical Aspects of Entrepreneurship. The American Economic Review, 79(3), 519-535.

Flórez, C. (2002). The function of the urban informal sector in employment. Evidence from Colombia 1984-2000. Bogotá, Colombia: Documentos CEDE, No. 2002-04, Universidad de los Andes.

García, G. (2005). El componente local de la informalidad laboral para las 10 principales áreas metropolitanas de Colombia, 1988-2000. Desarrollo y Sociedad, 56, 103-146. https://doi.org/10.13043/dys.56.4.

Greene, W.H. (2012). Econometric Analysis ( $7^{\text {th }}$ ed.). Madrid: Prentice Hall.

Guataquí, J.C., García, A.F., \& Rodríguez, M. (2009). Estimaciones de los determinantes de los ingresos laborales en Colombia con consideraciones diferenciales para asalariados y cuenta propia. Bogotá: Documentos de Trabajo, №. 70, Facultad de Economía, Universidad del Rosario.

Guataquí, J.C., García, A.F., \& Rodríguez, M. (2011). El Perfil de la Informalidad Laboral en Colombia. Bogotá, Colombia: Documentos de Trabajo, No. 95, Facultad de Economía, Universidad del Rosario.

Hamilton, B.H. (2000). Does Entrepreneurship Pay? An Empirical Analysis of the Returns of SelfEmployment. Journal of Political Economy, 108(3), 604-631. https://doi.org/10.1086/262131.

Heckman, J.J. (1976). The common structure of statistical models of truncation, sample selection and limited dependent variables and a simple estimator for such models. Annals of Economic and Social Measurement, 5(4), 475-492.

Heckman, J.J. (1979). Sample Selection Bias as a Specification Error. Econometrica: Journal of the Econometric Society, 47(1), 153-161. https://doi.org/10.2307/1912352.

Hurst, E., \& Pugsley, B. (2010). The Non Pecuniary Benefits of Small Business Ownership. Chicago: Working paper, University of Chicago.

Idrovo, F.K., Verdesoto, O.S., Valencia, E.R., \& Córdova, V.H. (2020). Modelo de ecuaciones estructurales para determinar la intención de emprendimiento de estudiantes de posgrado. Métodos Cuantitativos para la Economía y la Empresa, 30, 346-357. https://doi.org/10.46661/revmetodoscuanteconempresa.3715.

Jovanovic, B. (1994). Entrepreneurial choice when people differ in their management and labor skills. Small Business Economics, 6(3), 185-192.

Kaplan, E.L., \& Meier, P. (1958). Nonparametric Estimation from Incomplete Observations. Journal of the American Statistical Association, 53(282), 457-481. https://doi.org/10.2307/2281868.

Kihlstrom, R.E., \& Laffont, J.J. (1979). A General Equilibrium Entrepreneurial Theory of Firm Formation Based on Risk Aversion. The Journal of Political Economy, 87(4), 719-748. https://doi.org/10.1086/260790.

Knight, F.H. (1921). Risk, uncertainty and profit (1 ${ }^{\mathrm{a}}$. ed.). Boston, MA: Hart, Schaffner \& Marx, Houghton Mifflin Co.

Kumar, A., \& Schuetze, H.J. (2007). Self-Employment and Labor Market Policies. Victoria, Canadá: Discussion Paper, Department of Economics, University of Victoria. 
Lucas, R.E. (1978). On The Size Distribution of Business Firms. The Bell Journal of Economics, 9(2), 508-523. https://doi.org/10.2307/3003596.

Maloney, W.F. (2004). Informality Revisited. World development, 32(7), 1159-1178. https://doi.org/10.1016/j.worlddev.2004.01.008.

Martínez, G., Saavedra, R.E., \& Morones, A.L. (2020). Capital Social como factor de emprendimiento en los países de la OCDE: implementación de un modelo con datos de panel. Métodos Cuantitativos $\begin{array}{llllll}\text { para la Economía } y & \text { la } & \text { Empresa, } & 30,\end{array}$ https://doi.org/10.46661/revmetodoscuanteconempresa.3512.

Meager, N. (1992). Does unemployment lead to self-employment? Small Business Economics, 4, 87103. https://doi.org/10.1007/BF00389850.

Meghir, C., Narita, R., \& Robin, J.M. (2015). Wages and Informality in Developing Countries. American Economic Association, 105(4), 1509-1546. https://doi.org/10.1257/aer.20121110.

Mondragón, V., \& Peña, X. (2010). Business Ownership and Self-Employment in Developing Economies: The Colombian Case. En International Differences in Entrepreneurship (pp. 89-127). Chicago: University of Chicago. https://doi.org/10.7208/chicago/9780226473109.003.0004.

Mortensen, D., \& Pissarides, C. (1994). Job creation and job destruction in the theory of unemployment. Review of Economic Studies, 61(3), 397-415. https://doi.org/10.2307/2297896.

Núñez, J. (2002). Empleo informal y evasión fiscal en Colombia. Bogotá, Colombia: Archivos de Economía, No. 210, Departamento Nacional de Planeación.

Posso, C. (2010). Desigualdad salarial en Colombia 1984-2005: cambios en la composición del mercado laboral y retornos a la educación postsecundaria. Desarrollo y Sociedad, 66, 65-113. https://doi.org/10.13043/dys.66.3.

Quiñones, M. (2010). Canales de búsqueda de empleo y duración del desempleo en Colombia. Perfil de Coyuntura Económica, 16, 133-154.

Rees, H., \& Shah, A. (1986). An Empirical Analysis of Self-employment in the U.K. Journal of Applied Econometrics, 1(1), 95-108. https://doi.org/10.1002/jae.3950010107.

Ribero, R. (2003). Gender dimensions of non-formal employment in Colombia. Bogotá, Colombia: Documentos CEDE, $\mathrm{N}^{\circ}$. 2003-04, Universidad de los Andes.

Salinas, J.D., \& Aragón, D. (2011). Estructura de ingresos para trabajadores asalariados y por cuenta propia en la ciudad de Ibagué. Medellín: Borradores Departamento de Economía, No. 44, Universidad de Antioquia.

Sánchez, R.M. (2018). Trabajo Cuenta Propia en Colombia: Caracterización, Análisis y Evolución Reciente. Revista Estado y Políticas Públicas, 9, 61-79.

Santa María, S.M., Prada, L.C., \& Mujica, P.A. (2009). Oportunidades, desafios y barreras de la movilidad laboral en Colombia: reflexiones para la población en pobreza extrema y moderada. Bogotá: Working Paper No. 42, Centro de Investigación Económica y Social, Fedesarrollo.

Schumpeter, J.A. (1950). Capitalism, Socialism and Democracy ( $3^{\text {rd }}$ ed.). New York: Harper \& Row. 
Suárez, C. (2020). El trabajador por cuenta propia en América Latina. En A. d. Laboral, El mundo de trabajo y el sistema de salud colombiano en la encrucijada del Coronavirus (págs. 28-43). Medellín, Colombia: Escuela Nacional Sindical.

Tokman, V.E. (1987). El sector informal: quince años después. El Trimestre Económico, 54(3), 513536.

Uribe, J.I., \& Gómez, L. (2004). Canales de búsqueda de empleo en el mercado laboral colombiano 2003. Cali: Documento de Trabajo N $\mathrm{N}^{\mathrm{s}}$.77, Centro de Investigación y Domentación Socioeconómica, CIDSE, Universidad del Valle, Colombia.

Uribe, J.I., \& Ortiz, C.H. (2004). Una Propuesta de Conceptualización y Medición del Sector Informal. Santiago de Cali, Colombia: Documentos de Trabajo, No. 76, Facultad de Ciencias Sociales y Económicas, Universidad del Valle.

Viáfara, C., \& Uribe, J. (2009). Duración del desempleo y canales de búsqueda de empleo en Colombia. Revista de Economía Institucional, 11(21), 139-160.

White, H. (1980). A Heteroskedasticity-Consistent Covariance Matrix Estimator and a Direct Test for Heteroskedasticity. Econometrica, 48(4), 817-838. https://doi.org/10.2307/1912934.

Wooldridge, J. (2010). Introducción a la econometría. Un enfoque moderno (4a ed.). México: Cengage Learning Editores, S.A. 


\section{Annexes}

Annex 1. Characteristics of own-account workers, by diploma obtained in Colombia, 2010 and 2013.

\begin{tabular}{r|r|r|r|r}
\hline & \multicolumn{2}{|c|}{$\mathbf{2 0 1 0}$} & \multicolumn{2}{c}{$\mathbf{2 0 1 3}$} \\
\cline { 2 - 5 } None & \multicolumn{1}{|c|}{ Informal } & \multicolumn{1}{c|}{ Formal } & \multicolumn{1}{c}{ Informal } & \multicolumn{1}{c}{ Formal } \\
\hline High school & $57.00 \%$ & $21.00 \%$ & $54.0 \%$ & $20.0 \%$ \\
\hline Technical-technological & $31.0 \%$ & $27.00 \%$ & $32.00 \%$ & $23.0 \%$ \\
\hline $\begin{array}{r}\text { University or } \\
\text { postgraduate }\end{array}$ & $6.0 \%$ & $12.0 \%$ & $9.00 \%$ & $17.00 \%$ \\
\hline Total & $100.00 \%$ & $40.00 \%$ & $6.00 \%$ & $40.0 \%$ \\
\hline Souryyyy & $100.00 \%$ & $100.00 \%$ & $100.0 \%$ \\
\hline
\end{tabular}

Source: Authors' elaboration based on data from GEIH 2010, 2013.

Annex 2. Results of the selection equation for probability models (binomial and multinomial) of ownaccount workers in Colombia, 2010 and 2013.

\begin{tabular}{|c|c|c|c|c|}
\hline \multirow{2}{*}{ Variable } & 2010 & 2010 & 2013 & 2013 \\
\hline & GISH & CLS & GISH & CLS \\
\hline Education & $0.031 * * *$ & $0.053 * * *$ & $0.035 * * *$ & $0,047 * * *$ \\
\hline Age & $0.164 * * *$ & $0.145 * * *$ & $0.182 * * *$ & $0,147 * * *$ \\
\hline Square age & $-0,002 * * *$ & $-0,001 * * *$ & $-0,002 * * *$ & $-0.001 * * *$ \\
\hline Gender & $0,725 * * *$ & $1,384 * * *$ & $0,811 * * *$ & $1,173 * * *$ \\
\hline Head of household & $0,405 * * *$ & $0,288 * * *$ & $0,395 * * *$ & $0,346^{* * *}$ \\
\hline Marital status & $-0,064 * * *$ & $-0,366 * * *$ & $-0,054 * * *$ & $-0,385 * * *$ \\
\hline Own residential property & $-0.172 * * *$ & $-0,207 * * *$ & $-0.266^{* * *}$ & $-0,115^{* *}$ \\
\hline Social stratum 1 & $271 * * *$ & 0,071 & $0,262 * * *$ & 0.036 \\
\hline Social stratum 2 & $0,206 * * *$ & 0,151 & $0,274 * * *$ & 0,027 \\
\hline Social stratum 3 & $0.077 * * *$ & 0.117 & $0,110 * * *$ & 0.040 \\
\hline Constant & $-3.095 * * *$ & $-2.68 * * *$ & $-3,720 * * *$ & $-2,508 * * *$ \\
\hline Number of observations & 361,528 & 4,557 & 313,372 & 5,572 \\
\hline Wald Test & 27.01 & $203 * * *$ & 21.02 & $299 * *$ \\
\hline $\boldsymbol{o}=\mathbf{0}$ & $5.16^{*}$ & $8.05 * *$ & $13.02 * * *$ & $5.24 * *$ \\
\hline
\end{tabular}

*** Significant at $1 \% ; * * 5 \% ; * 10 \%$

Source: Authors' calculations based on data from GISH and CLS, 2010 y 2013. 